\title{
Histone modifications in DNA damage response
}

\author{
Lin-Lin Cao ${ }^{1,4}$, Changchun Shen ${ }^{1} \&$ Wei-Guo $\mathrm{Zhu}^{1,2,3^{*}}$ \\ ${ }^{1}$ Key Laboratory of Carcinogenesis and Translational Research (Ministry of Education), State Key Laboratory of Natural and Biomimetic \\ Drugs, Beijing Key Laboratory of Protein Posttranslational Modifications and Cell Function, Department of Biochemistry and Molecular \\ Biology, Peking University Health Science Center, Beijing 100191, China; \\ ${ }^{2}$ Peking University-Tsinghua University Joint Center for Life Sciences, Beijing 100084, China; \\ ${ }^{3}$ Shenzhen University School of Medicine, Shenzhen 518060, China; \\ ${ }^{4}$ Department of Clinical Laboratory, Peking University People’s Hospital, Beijing 100044, China
}

Received August 17, 2015; accepted November 4, 2015; published online January 27, 2016

\begin{abstract}
DNA damage is a relatively common event in eukaryotic cell and may lead to genetic mutation and even cancer. DNA damage induces cellular responses that enable the cell either to repair the damaged DNA or cope with the damage in an appropriate way. Histone proteins are also the fundamental building blocks of eukaryotic chromatin besides DNA, and many types of post-translational modifications often occur on tails of histones. Although the function of these modifications has remained elusive, there is ever-growing studies suggest that histone modifications play vital roles in several chromatin-based processes, such as DNA damage response. In this review, we will discuss the main histone modifications, and their functions in DNA damage response.
\end{abstract}

DNA damage response, histone modifications, chromatin, DNA repair

Citation: $\quad$ Cao, L.L., Shen, C., and Zhu, W.G. (2016). Histone modifications in DNA damage response. Sci China Life Sci 59, 257-270. doi: $10.1007 / \mathrm{s} 11427-016-5011-\mathrm{z}$

\section{INTRODUCTION}

Eukaryotic cells are exposed to numbers of factors that cause DNA lesions and genomic integrity is continually challenged. Chemicals, UV radiation, ionizing radiation outside the cells and reactive oxygen species, S-adenosylmethionine inside the cells are known to induce various DNA damage (Lord and Ashworth, 2012). DNA lesions interfere with DNA replication and transcription, and if they are not repaired correctly, they can have deleterious effects, such as mutations and even wider-scale genome aberrations (Polo and Jackson, 2011). DNA damage is closely associated with many human diseases, including cancer, neurodegenerative disorders, immune deficiencies, infertility and cardiovascular disease (Ciccia and Elledge, 2010; Jackson

*Corresponding author (email: zhuweiguo@bjmu.edu.cn) and Bartek, 2009).

In order to preserve genomic integrity, DNA damage must be repaired precisely. Indeed, eukaryotic cells have developed several highly conserved DNA repair pathways to counteract different types of damage, including (i) Base excision repair. (ii) Nucleotide excision repair. (iii) Mismatch repair. (iv) Nonhomologous end-joining (NHEJ)mediated DNA double-strand break repair. (v) Homologous recombination (HR)-mediated DNA double-strand break repair (Sancar et al., 2004; Williamson et al., 2012). Different repair pathways are mediated by different repair factors, contributing to a series of large networks safeguarding the genomic DNA (Sancar et al., 2004). It has been clear that histone modification is also a critical part of these networks, and the roles of histone modification in DNA damage response have been well demonstrated in recent studies (Miller and Jackson, 2012; Sulli et al., 2012). 
In eukaryotes, chromatin is composed of repeating units of nucleosomes connected by linker DNA. The core component of nucleosome is histone octamer, which is formed by two copies each of histone H2A, H2B, H3, H4 (Margueron and Reinberg, 2010; Talbert and Henikoff, 2010), whereas histone H1 binds to the linker DNA between nucleosomes. Histones are easily catalyzed by histone modification enzymes to form different kinds of posttranslational modifications, such as methylation, acetylation and phosphorylation (Campos and Reinberg, 2009; Kouzarides, 2007). Until now, more than a dozen types of histone modifications and hundreds of modification sites altogether have been found (Arnaudo and Garcia, 2013; Dai et al., 2014; Kouzarides, 2007; Tan et al., 2011) (Figure 1).

Histone modifications play critical roles in many biological processes by regulating chromatin structure and function. There are several ways for histone modifications to exert their functions. At first, it is well known that the DNA-histone interaction in the chromatin structure is mediated by the attraction between negatively charged DNA backbone and positively charged lysine and arginine residues of histones (Bannister and Kouzarides, 2011). Some modifications including lysine acetylation, lysine citrullination and Serine/Threonine phosphorylation, can change the charge of the amino acid residues of histones and thereby regulate the compaction of chromatin (Gyorgy et al., 2006; Strahl and Allis, 2000). In addition, histone modifications can serve as high-affinity binding sites or platforms for the proteins containing specific binding domains. For example, the PHD zinc-finger domains, chromodomains and Tudor domains bind specifically to the methylated lysines, while bromodomains recognize acetylated lysines with high affinity (Yun et al., 2011). Furthermore, there are intricate crosstalks between different histone modifications, and one histone modification can regulate the activities of chromatin by influencing another histone mark. For example, the existence of some histone modifications can inhibit the generation of other modifications at the same amino acid residue, and modulating the formation of modifications at the residues nearby because of steric effect (Lee et al., 2010b; Suganuma and Workman, 2008). In general, histone modifications regulate chromatin activities in different ways.

Histone modification is involved in a lot of physiological and pathological processes. Firstly, histone modification is closely related to tumorigenesis and cancer progression. For instance, H3K36 dimethylation is the transcriptional activator of DUSP3 (dual-specificity phosphatase 3) gene, whose protein dephosphorylates ERK1/2 (extra cellular-regulated kinase 1/2) and downregulates ERK1/2 activity. Histone demethylase KDM2A (lysine-specific demethylase 2A), which is capable of erasing $\mathrm{H} 3 \mathrm{~K} 36$ dimethylation and repressing DUSP3 expression, is frequently overexpressed in lung tumors, and promotes lung tumorigenesis and metastasis by enhancing ERK1/2 signaling (Wagner et al., 2013). In addition, histone modification plays a role in cell metabolism. It has been demonstrated that histone demethylase KDM3A directly regulates the metabolic gene Ppara and Ucpl expression, both of which are the important regulator of energy balance, by demethylating H3K9me1/2 (Tateishi et al., 2009). Moreover, histone modification is the modulator of stem cell division and differentiation. There is a large cohort of developmental gene promoters containing bivalent chromatin domain, which is enriched simultaneously with the transcriptionally active histone mark H3K4me3 and transcriptionally repressive histone mark

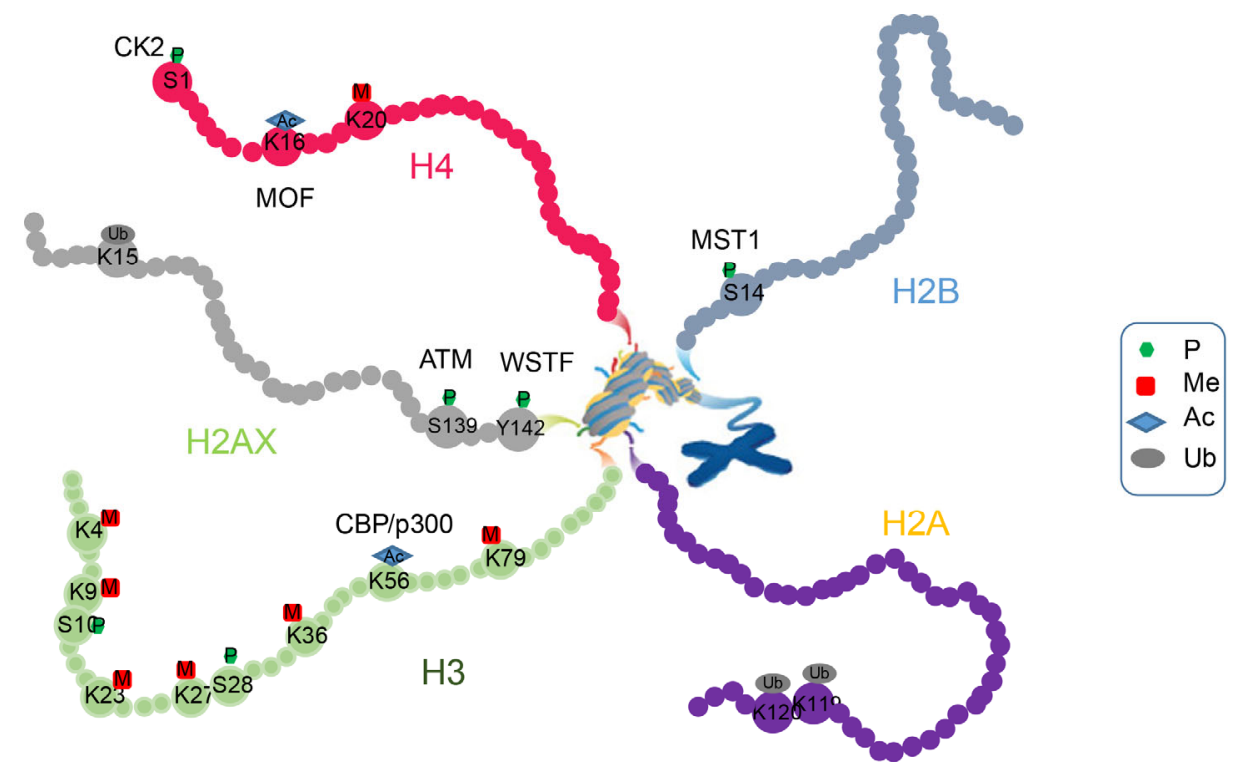

Figure 1 Many histone modifications are involved in DNA damage response. The representative modification sites are shown here. 
H3K27me3, and stem cell fate is controlled by the specific bivalent domain (Voigt et al., 2013). Furthermore, histone modification is also tightly correlated with DNA damage at every stage of cell response to DNA damage (Rossetto et al., 2010). In this review, we will summarise and discuss the most recent studies, and describe the functions of each histone modification in DNA damage response (Figure 1).

\section{PHOSPHORYLATION}

One of the first histone modification events correlated with DNA damage response is the phosphorylation of the $\mathrm{H} 2 \mathrm{~A}$ variant $\mathrm{H} 2 \mathrm{AX}$, and the phosphorylated $\mathrm{H} 2 \mathrm{AX}$ is referred as $\gamma \mathrm{H} 2 \mathrm{AX}$. H2AX phosphorylation occurs within minutes after exposure to DNA damage, and the phosphorylation site is Serine 139 (S139) of the H2AX human variant or Serine 129 (S129) of yeast H2A in a unique conserved SQ motif in the C-terminal tail (Downs et al., 2000; Rogakou et al., 1998). It has been described that ATR (ataxia-telangiectasia mutated and $\operatorname{Rad} 3$ related) is responsible for $\gamma \mathrm{H} 2 \mathrm{AX}$ foci formation in response to replication stress (Ward and Chen, 2001), while ATM (ataxia-telangiectasia mutated) and DNA-PK (DNA-dependent protein kinase) function redundantly to phosphorylate $\mathrm{H} 2 \mathrm{AX}$ after exposure to ionizing radiation (Stiff et al., 2004) (Figure 2). $\gamma \mathrm{H} 2 \mathrm{AX}$ spreads over a large region (over $1 \mathrm{Mb}$ in human cells) around a DNA break site (Downs et al., 2004; Rogakou et al., 1999; Shroff et al., 2004; Unal et al., 2004). Therefore, it is easily detected by specific antibodies against $\gamma \mathrm{H} 2 \mathrm{AX}$ in fluorescence microscopy and chromatin immunoprecipitation analysis, and has been commonly used as a biomarker of DNA damage nuclear foci (Bonner et al., 2008; Mah et al., 2010). $\gamma \mathrm{H} 2 \mathrm{AX}$ distributes on both sides of a DNA break in an asymmetrical manner because of transcription state of the genes surrounding DNA damage site (Iacovoni et al., 2010). In addition, the pattern of $\gamma \mathrm{H} 2 \mathrm{AX}$ is different on different chromatin regions, and $\gamma \mathrm{H} 2 \mathrm{AX}$ foci formation in euchromatin is more efficient than that in heterochromatin in yeast and mammals (Kim et al., 2007).

It is clear that $\gamma \mathrm{H} 2 \mathrm{AX}$ is essential for DNA damage response. At first, $\gamma \mathrm{H} 2 \mathrm{AX}$ is required for the error-free $\mathrm{HR}$ repair and genome stability, and $\mathrm{H} 2 \mathrm{AX}$ deficient mice or cells show increased use of error-prone single-strand annealing, enhanced radiosensitivity and oncogenic translocations, resulting in increased rates of tumorigenesis and cancer development (Bassing et al., 2002; Bassing et al., 2003; Celeste et al., 2003a; Celeste. et al., 2002; Xie et al., 2004). Additionally, although $\gamma \mathrm{H} 2 \mathrm{AX}$ is dispensable for the constitution of the primary DNA damage signal and the initial recruitment of repair factors, it is critical for the accumulation and retention of Rad50, Rad51, BRCA1 (breast cancer 1), MDC1 (mediator of DNA damage checkpoint 1) in human cells and 53BP1 homolog in yeast in response to DNA damage (Celeste et al., 2003b; Javaheri et al., 2006;
Nakamura et al., 2004; Paull et al., 2000; Stucki et al., 2005). Moreover, $\gamma \mathrm{H} 2 \mathrm{AX}$ does not affect chromatin organization in the initial stage of DNA damage recognition and signaling (Fink et al., 2007). However, it is necessary to open the chromatin structure to facilitate access for the repair factors around the damage sites after the initial signaling, and histone modifiers and ATP-dependent chromatin remodelers are required at the DNA breaks (Osley et al., 2007). In fact, $\gamma \mathrm{H} 2 \mathrm{AX}$ plays a role in recruiting $\mathrm{NuA} 4$, INO80 chromatin remodeling complexes and promotes histone acetylation to render the chromatin environment surrounding the DNA breaks more accessible for the repair factors (Downs et al., 2004; Lee et al., 2010a; Morrison et al., 2004; van Attikum et al., 2004).

Because of the essential role in DNA damage response, $\gamma \mathrm{H} 2 \mathrm{AX}$ must be tightly regulated. Indeed, many factors are capable of modulating $\gamma \mathrm{H} 2 \mathrm{AX}$. For example, ATM promotes $\gamma \mathrm{H} 2 \mathrm{AX}$ formation to maximal distance and maintains $\gamma \mathrm{H} 2 \mathrm{AX}$ densities, while MDC1 is required for $\gamma \mathrm{H} 2 \mathrm{AX}$ formation at high densities near damage sites, but not for generation of $\gamma \mathrm{H} 2 \mathrm{AX}$ over distal sequences (Savic et al., 2009). In addition, SWI/SNF chromatin remodeling complex facilitates $\gamma \mathrm{H} 2 \mathrm{AX}$ induction and binds to $\gamma \mathrm{H} 2 \mathrm{AX}$-containing nucleosomes (Lee et al., 2010a; Park et al., 2006). Moreover, evidence from yeast models suggests that yINO80 is required for maintaining a high level of $\gamma \mathrm{H} 2 \mathrm{AX}$ during DNA damage response, while ySWR1 functions antagonistically and plays a role in replacing $\gamma \mathrm{H} 2 \mathrm{AX}$ with the $\mathrm{H} 2 \mathrm{AZ}$ variant (Papamichos-Chronakis et al., 2006). Last but not least, $\gamma \mathrm{H} 2 \mathrm{AX}$ has to be eliminated from chromatin after the repair process is completed. It can be achieved either by the function of SWR1 (Papamichos-Chronakis et al., 2006), or by $\gamma \mathrm{H} 2 \mathrm{AX}$ dephosphorylation. Many phosphatases have the ability to erase $\gamma \mathrm{H} 2 \mathrm{AX}$, including PP2A, PP4C, PP6, Wip1 in human cells and yPph3 in yeast (Figure 2). $\gamma \mathrm{H} 2 \mathrm{AX}$ dephosphorylation is important for DNA repair and efficient recovery from the DNA damage checkpoint (Chowdhury et al., 2005; Chowdhury et al., 2008; Douglas et al., 2010; Keogh et al., 2006; Macurek et al., 2010; Nakada et al., 2008). In general, $\gamma \mathrm{H} 2 \mathrm{AX}$ is an important marker of DNA break sites and essential modulator of DNA damage response, and is also tightly regulated during the DNA repair process.

In addition to $\gamma \mathrm{H} 2 \mathrm{AX}$, there are some other phosphorylation events occurring on histone $\mathrm{H} 2 \mathrm{AX}$ or other histones linked with DNA damage response. For instance, H2AX is also phosphorylated on its C-terminal tyrosine 142 (Y142) by the non-canonical tyrosine kinase WSTF (WilliamsBeuren syndrome transcription factor), and dephosphorylated by tyrosine phosphatase EYA (Cook et al., 2009; Xiao et al., 2009). Y142 is constitutively phosphorylated under normal growth conditions, and becomes gradually dephosphorylated during the DNA damage response (Xiao et al., 2009). WSTF and/or Y142 phosphorylation not only 


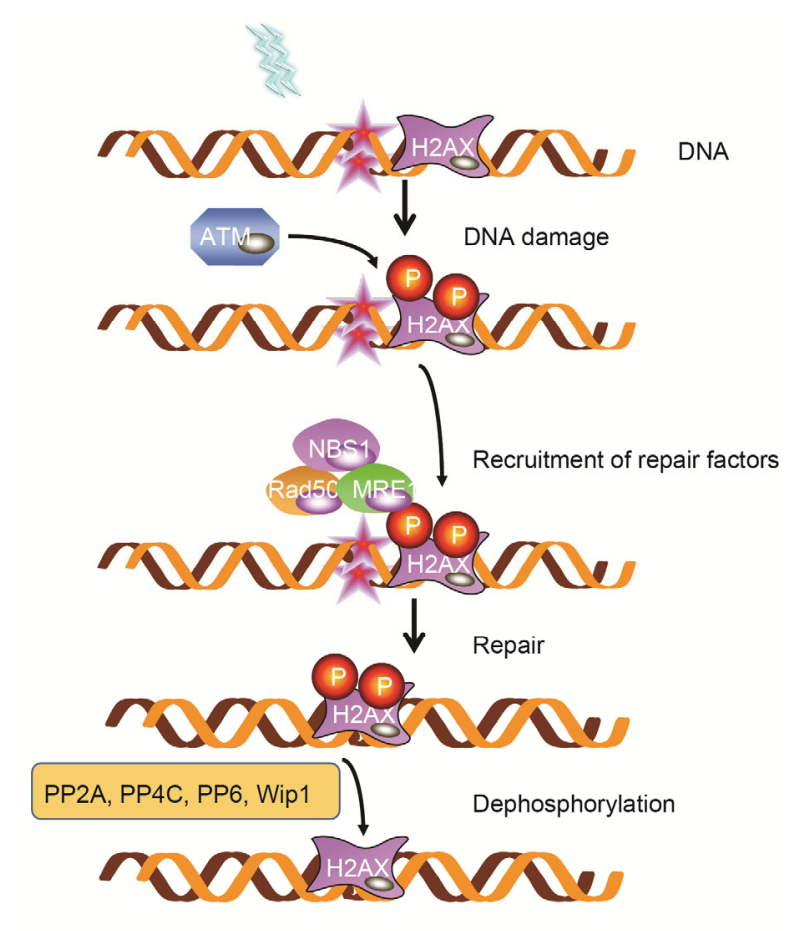

Figure 2 The role of $\gamma \mathrm{H} 2 \mathrm{AX}$ in DNA damage response. In response to DNA double-strand break, histone $\mathrm{H} 2 \mathrm{AX}$ is quickly phosphorylated by ATM or other kinases, after which many repair factors are recruited to the DNA damage site to promote DNA repair. As long as the DNA repair process is completed, $\gamma \mathrm{H} 2 \mathrm{AX}$ will be dephosphorylated by some phosphatases, such as PP2A, PP4C, PP6, Wip1.

regulate the recruitment of active ATM and MDC1, and the maintenance of $\gamma \mathrm{H} 2 \mathrm{AX}$ upon DNA damage (Xiao et al., 2009), but also further determine repair/survival versus apoptotic responses to DNA damage (Cook et al., 2009). Additionally, phosphorylation of threonine 101 (T101) on $\mathrm{H} 2 \mathrm{AX}$ is identified as a DNA damage responsive modification as well. T101 mutation increases $\gamma$ radiation (IR) sensitivity of ES cells, but does not affect DNA repair efficiency (Xie et al., 2010). Moreover, histone H2B is phosphorylated on serine 14 (S14) by protein kinase MST1 (mammalian sterile twenty-like kinase 1) following DNA damage, and H2BS14ph foci appears at the late time points in a $\gamma \mathrm{H} 2 \mathrm{AX}$-dependent manner (Cheung et al., 2003; FernandezCapetillo et al., 2004). Furthermore, the N-terminal serine 1 (S1) of $\mathrm{H} 4$ in nucleosomes proximal to the break sites is phosphorylated by casein kinase 2 (CK2) at the end of the repair process. H4S1 phosphorylation inhibits $\mathrm{H} 4$ acetylation to stabilize the nucleosome during chromatin restoration, and promotes NHEJ-mediated double-strand break repair (Cheung et al., 2005; Utley et al., 2005). Finally, histone $\mathrm{H} 3$ phosphorylation, such as H3S10p and H3S28p, decreases upon DNA damage due to the activation of cell cycle checkpoint and thus reduced mitotic cells (Tjeertes et al., 2009).

\section{METHYLATION}

The second most common histone modification linked with DNA damage response is histone methylation. Histone methylation occurs at specific sites on $\mathrm{H} 3$ and $\mathrm{H} 4$ such as $\mathrm{H} 3 \mathrm{~K} 4, \mathrm{H} 3 \mathrm{~K}$, H3K27, H3K36, H3K79 and H4K20. It is performed by histone methyltransferases and reversed by histone demethylases, indicating that it is dynamically regulated in eukaryotic cells. Histone methyltransferases refer to a family of proteins containing the catalytic SET domain except the H3K79 methyltransferase DOT1L, while two families of histone demethylases have been reported, including flavin adenine dinucleotide (FAD)-dependent histone demethylases and Jmjc domain-containing histone demethylases. Many histone methyltransferases/demethylases, as well as their targeted histone methylations, are involved in DNA damage response.

H3K9 methylation is critical for genome stability and DNA damage response. At first, $\mathrm{H} 3 \mathrm{~K} 9 \mathrm{me} 3$ is an essential histone marker of heterochromatin (Grewal and Jia, 2007). H3K9 methyltransferase SUV39H1 is required for the maintenance of heterochromatic state, and its methylation by SET7/9 impairs its enzymatic activity resulting in decreased H3K9me3 and heterochromatin instability (Peng and Karpen, 2009; Wang et al., 2013). Next, H3K9 methylation is important for the cellular response to DNA damage, but the role of $\mathrm{H} 3 \mathrm{~K} 9$ methylation is different at the early-stage and late-stage of DNA damage response. DNA damage immediately induces the loading of a protein complex containing KAP-1, HP1, SUV39H1 onto the DNA double-strand breaks, and therefore upregulates the level of H3K9me3 nearby. With the assistance of HP1, H3K9me3 can spread over tens of kilobases away from the damage sites to form a large repressive heterochromatin domain (Ayrapetov et al., 2014). Subsequently, HP1 is released from chromatin, and histone acetyltransferase Tip60 binds to H3K9me3 via its chromodomain. The enrichment of Tip60 activates its acetyltransferase activity, and stimulates the subsequent acetylation and activation of ATM at the damage sites (Ayoub et al., 2008; Ayrapetov et al., 2014; Sun et al., 2010; Sun et al., 2009). Therefore, H3K9 methylation and heterochromatin formation is required for ATM activation, and ATM-mediated DNA damage signaling such as $\gamma \mathrm{H} 2 \mathrm{AX}$ localization at the early phase of DNA damage response (Sasaki et al., 2014). However, because the chromatin adjacent to the damaged DNA needs to be open in order to increase the accessibility of repair proteins, H3K9 methylation has to be reversed to promote the repair process. It has been demonstrated that DNA damage induces the degradation of G9a/GLP, which results in decreased H3K9me2 at the promoters of $I L-6$ and $I L-8$ in senescent cells (Takahashi et al., 2012). In addition, H3K9me2/3 demethylases KDM4B and KDM4D are recruited to the DNA damage sites mediated by PARP1, and are responsible for H3K9 demethylation (Khoury-Haddad et al., 2014; Young 
et al., 2013). However, a recent study reveals that $\mathrm{H} 3 \mathrm{~K} 9 \mathrm{me} 2$ is required for BARD1 and BRCA1 retention at sites of DNA damage, thus promoting HR repair in $S$ phase of cell cycle (Wu et al., 2015). It indicates that H3K9me3 is removed, but $\mathrm{H} 3 \mathrm{~K} 9 \mathrm{me} 2$ is reserved at damaged DNA.

Similar to H3K9 methylation, H3K36 methylation is an important histone marker for recruiting repair factors as well. H3K36 methyltransferase Metnase promotes DNA integration by opening chromatin and facilitating joining of DNA ends (Lee et al., 2005). More importantly, H3K36me2 is induced in response to DNA double-strand break, and Metnase itself and its phosphorylation by Chk1 (checkpoint kinase 1) are responsible for the increase of H3K36me2, which is a platform for recruiting $\mathrm{Ku} 70$ to enhance the activity of NHEJ (Fnu et al., 2011; Hromas et al., 2012). Additionally, our group discovered that the phosphorylation of H3K36 demethylase KDM2A mediated by ATM is also required for $\mathrm{H} 3 \mathrm{~K} 36 \mathrm{me} 2$ induction, and $\mathrm{H} 3 \mathrm{~K} 36 \mathrm{me} 2$ is capable of favoring MRE11 complex localization through the direct interaction between H3K36me2 and NBS1 (Cao et al., 2015). Compared to $\mathrm{H} 3 \mathrm{~K} 36 \mathrm{me} 2$, it seems that H3K36me3 exerts more complicated functions in DNA damage response although it is not induced by DNA damage. At first, Set2-dependent H3K36me3 is essential for the loading of mismatch recognition protein hMuts $\alpha$ via direct interaction with the hMSH6 PWWP domain, and is required for DNA mismatch repair to ensure the fidelity of DNA replication ( $\mathrm{Li}$ et al., 2013). However, the role of H3K36me3 in cellular response to DNA double-strand break is controversial at present. One study in fission yeast indicates that $\mathrm{H} 3 \mathrm{~K} 36 \mathrm{me} 3$ is cell cycle regulated, peaking in $\mathrm{G} 1$ when NHEJ occurs and decreasing in S and G2/M phases, and H3K36me3 reduces chromatin accessibility, impairs DNA end resection and HR (Pai et al., 2014). Other studies show that Set2-dependent H3K36me3 is critical for appropriate resection and HR through recruiting repair factors CtIP (retinoblastoma binding protein 8), RPA (replication protein A1) and Rad51 (Jha and Strahl, 2014; Pfister et al., 2014). In the end, H3K36 demethylase Rph1 functions as a transcriptional repressor and inhibits the expression of DNA repair enzyme gene $P H R l$ and other stress-response genes by H3K36 demethylation, while DNA damage and environmental stress induce Rph1 phosphorylation and dissociation from chromatin to facilitate gene expression (Liang et al., 2011; Liang et al., 2013), indicating that H3K36 methylation is essential for DNA repair.

Although H3K79 methylation is also a pre-exiting histone modification and not induced by DNA damage (Huyen et al., 2004), it plays an extensive role in DNA damage response and the maintenance of genome stability. The best characterized function of $\mathrm{H} 3 \mathrm{~K} 79$ methylation is recruiting 53BP1 to DNA break sites. Dot1L-dependent H3K79 methylation is required for the localization of 53BP1 around damaged DNA and 53BP1 tandem Tudor domain binds to methylated H3K79 directly, resulting in the induction of 53BP1 phosphorylation and checkpoint activation (Giannattasio et al., 2005; Huyen et al., 2004; Wakeman et al., 2012; Wysocki et al., 2005). In addition, H3K79 methylation mediated by Dot1L promotes nucleotide excision repair, and H3K79R mutation increases the binding of histone deacetylase complex to eliminate histone acetylation and reduce DNA lesion accessibility to repair enzymes (Chaudhuri et al., 2009; Tatum and Li, 2011). Moreover, Dot1L and H3K79me3 contribute to favorable sister chromatid exchange during HR and facilitate HR repair (Conde et al., 2009; Rossodivita et al., 2014). Furthermore, there is crosstalk between H3K79 methylation and other histone methylations. For example, H3K79 methylation is important for the maintenance of heterochromatic mark H3K9 methylation and H4K20 methylation at centromeres and telomeres, and loss of $\mathrm{H} 3 \mathrm{~K} 79$ methylation results in heterochromatin instability (Jones et al., 2008). Lastly, it has been described that H3K79 methylation is critical for Mek1 autophosphorylation and activation, and thereby modulates the meiotic checkpoint response (Ontoso et al., 2013).

Another histone modification involved in 53BP1 localization is H4K20 methylation. H4K20 methyltransferase MMSET (Wolf-Hirschhorn syndrome candidate 1) regulates the induction of H4K20 methylation on histones around double-strand breaks, which in turn facilitates 53BP1 recruitment (Hajdu et al., 2011; Pei et al., 2011). In addition to MMSET, another two H4K20 methyltransferases Set8 and Set9 are also responsible for H4K20 methylation and the recruitment of 53BP1 (Dulev et al., 2014; Greeson et al., 2008; Oda et al., 2010; Sanders et al., 2004; Yan et al., 2009). Similar to H3K79 methylation, H4K20 methylation recruits 53BP1 via its tandem Tudor domain as well (Botuyan et al., 2006). Interestingly, histone demethylase KDM4A also contains a tandem Tudor domain, and it competes with 53BP1 for binding to methylated H4K20. In order to favor 53BP1 localization, KDM4A is degraded in a RNF8- and RNF168-dependent manner in response to DNA damage (Mallette et al., 2012). Actually, H4K20 methylation not only promotes 53BP1 localization, but also serves to modulate genome stability. H4K20me1/2/3 is required for maintenance of proper high order chromatin structure, and loss of H4K20 methylation impairs genomic integrity and may induce tumorigenesis (Oda et al., 2009; Sakaguchi and Steward, 2007; Schotta et al., 2008). In fact, global H4K20 methylation is much lower in bladder cancer samples than in normal tissues and has been proposed as a potential prognosis biomarker in bladder cancer (Schneider et al., 2011).

Other histone methylations such as $\mathrm{H} 3 \mathrm{~K} 27$ methylation and $\mathrm{H} 3 \mathrm{~K} 4$ methylation are also involved in DNA damage response. DNA double-strand break initiates the recruitment of polycomb group proteins EZH2, SUZ12, CBX8, which constitute a repressive chromatin structure at the sites of DNA damage via H3K27 methylation to block transcription 
and facilitate DNA repair (Campbell et al., 2013; Chou et al., 2010; O'Hagan et al., 2008). As for H3K4 methylation, it seems to be reversed upon DNA damage. At first, LSD1 (lysine-specific demethylase 1), as well as its Caenorhabditis elegans ortholog Spr-5, is enriched on double-strand break sites and responsible for $\mathrm{H} 3 \mathrm{~K} 4 \mathrm{me} 1 / 2$ demethylation, resulting in increased recruitment of repair factors (Mosammaparast et al., 2013; Nottke et al., 2011). In addition, KDM5A and KDM5B, the H3K4me2/3 demethylases, are recruited to damaged DNA to induce loss of $\mathrm{H} 3 \mathrm{~K} 4 \mathrm{me} 2 / 3$, and required for efficient DNA repair ( $\mathrm{Li}$ et al., 2014; Seiler et al., 2011). However, the role of H3K4 methylation in DNA damage response is disputable, because it has been reported that the yeast Set1p methyltransferase as well as its substrate $\mathrm{H} 3 \mathrm{~K} 4 \mathrm{me} 3$ become detectable on a newly created double-strand break in budding yeast cells, and this enrichment of Set1p and H3K4me3 are important for DNA repair by NHEJ (Faucher and Wellinger, 2010). Moreover, the role of H3K4 methylation in nucleotide excision repair is interesting, and H3K4R mutation exerts different impacts on nucleotide excision repair on different genomic loci (Chaudhuri et al., 2009). In our previous studies, we also described the critical role of an $\mathrm{H} 3 \mathrm{~K} 4$ methyltransferase SET7/9 in DNA damage response and oxidative stress, but through methylating non-histone proteins (Shen et al., 2015; Wang et al., 2013). At last, H3K23 trimethylation (H3K23me3), a novel characterized histone modification, is reported to blocks DNA damage in pericentric heterochromatin during meiosis in Tetrahymena (Papazyan et al., 2014).

\section{ACETYLATION}

Histone acetylation has also been extensively studied in the context of DNA damage response modulation. It is wellknown that histone acetylation can influence chromatin structure (Shogren-Knaak et al., 2006; Turner et al., 1992). On the one hand, acetylation neutralizes the positively charged lysine residues, resulting in diminished interaction between DNA backbone and histones to facilitate chromatin decondensation and enhance the accessibility of nucleosomal DNA (Kouzarides, 2000; Shahbazian and Grunstein, 2007). On the other hand, it is capable of recruiting chromatin remodelling complex such as $\mathrm{SWI} / \mathrm{SNF}$ complex to modulate the chromatin structure (Lee et al., 2010a). Histone acetylation is dynamically regulated by histone acetyltransferases and histone deacetylases. Histone acetyltransferases are responsible for transferring an acetyl group from acetyl-coenzyme A to histone lysine residues, while histone deacetylases are able to remove the acetyl group of histones (Grunstein, 1997). Compared to histone methyltransferases/demethylases, histone acetyltransferases/deacetylases don't exhibit rigid site-specificity. For example, p300/CBP acetylate all four nucleosomal core histones equally well, and they exhibit multisite acetylation pattern in different histones (Roth et al., 2001).

Many histone acetyltransferases are involved in DNA damage response. At first, it is described that histone acetyltransferase MOF and its substrate H4K16 acetylation is required for IR-induced ATM activation (Gupta et al., 2005; Smith et al., 2005), ATM-dependent phosphorylation of DNA-PKcs (Sharma et al., 2010) and MDC1 recruitment (Li et al., 2010), and MOF depletion greatly decreased DNA double-strand break repair by both NHEJ and HR (Sharma et al., 2010). Interestingly, a recent study reveals that the proteasome activator PA200 in mice specifically recognizes acetylated H4K16 via its bromodomain-like regions, and targets the core histones for acetylation-mediated degradation by proteasomes in response to DNA double-strand break, thus relaxing the chromatin and promoting DNA repair (Qian et al., 2013). In addition, human CBP/p300 and yeast Rtt109 are responsible for H3K56 acetylation in vivo and is required for DNA replication and genome stability (Das et al., 2009; Han et al., 2007). It is reported that H3K56 acetylation are reduced initially in response to DNA damage, followed by full renewal of an acetylated state, and $\mathrm{H} 3 \mathrm{~K} 56 \mathrm{Ac}$ is colocalized with other proteins involved in DNA damage signaling pathways such as phospho-ATM, $\mathrm{CHK} 2$, and p53 at the sites of DNA repair (Battu et al., 2011; Tjeertes et al., 2009; Vempati et al., 2010). During the $\mathrm{S}$ phase of cell cycle, H3K56Ac is on the newly synthesized histone $\mathrm{H} 3$ that is incorporated into chromosomes (Masumoto et al., 2005), and it drives chromatin reassembly and checkpoint recovery after DNA repair with the assistance of histone chaperone Asf1 (Chen et al., 2008; Driscoll et al., 2007). H3K56Ac abrogation results in sensitivity to genotoxic agents that cause DNA strand breaks, genome instability and decreased sister chromatid recombination in the S phase (Munoz-Galvan et al., 2013; Wurtele et al., 2012). However, cells proceed into G2 phase after DNA replication fork damage repair is completed, and $\mathrm{H} 3 \mathrm{~K} 56$ acetylation largely disappears in G2 phase (Masumoto et al., 2005). In addition to p300/CBP, the acetyltransferase GCN5 in human cells is also able to acetylate H3K56 (Tjeertes et al., 2009), but GCN5 is responsible for H3K9 acetylation as well, thus stimulating the recruitment of repair factors in the nucleotide excision repair pathway (Guo et al., 2011). Moreover, the acetyltransferase Tip60 also plays a role in DNA damage response (Ikura et al., 2000). Human Tip60 or its yeast homolog Esal is recruited to DNA double-strand breaks in vivo by $\gamma \mathrm{H} 2 \mathrm{AX}$ (Bird et al., 2002; Downs et al., 2004), and it induces acetylation of histones surrounding DNA damage sites, thus resulting in chromatin relaxation and loading of repair proteins (Murr et al., 2006). Besides chromatin relaxation, Tip60-mediated acetylation of phospho-H2Av, $\gamma \mathrm{H} 2 \mathrm{AX}$ homolog in Drosophila melanogaster, induces the exchange of phospho-H2Av with unmodified H2Av (Kusch et al., 2004), while Tip60-dependent H4K16 acetylation diminishes 53BP1 binding to H4K20me2 and promotes HR repair (Tang et al., 2013). Tip60 depletion 
impairs homologous recombination and rendered cells sensitive to cisplatin (House et al., 2014; Miyamoto et al., 2008; Tang et al., 2013). Furthermore, similar to human $\mathrm{CBP} / \mathrm{p} 300$ or yeast Rtt109, histone acetyltransferase 1 in yeast and human cells is also required for the incorporation of acetylated H3 at sites of double-strand breaks, and facilitates subsequent recruitment of RAD51 to promote efficient homologous recombination (Qin and Parthun, 2002; Yang et al., 2013).

Histone deacetylation is also important for DNA repair and cell cycle progression. At first, loss of histone deacetylase Hdac3 in MEFs causes DNA damage and $\mathrm{S}$ phase checkpoint activation, indicating that Hdac3 is essential for genome stability during DNA replication (Bhaskara et al., 2008). In addition, in Saccharomyces cerevisiae, Sin3pmediated H4K16 deacetylation is required for 53BP1 binding to methylated H4K20, thus inducing efficient NHEJ repair (Hsiao and Mizzen, 2013; Jazayeri et al., 2004). Except for NHEJ, HR also triggers localized histone deacetylation by histone deacetylases Rpd3, Sir2, and Hst1 at DNA double-strand breaks, and the ability to modulate histone acetylation during HR is essential for cell viability (Tamburini and Tyler, 2005). Moreover, many histone deacetylases are responsible for the removal of $\mathrm{H} 3 \mathrm{~K} 56 \mathrm{Ac}$, including HDAC1, HDAC2, hSIRT1, hSIRT2, hSIRT3, yHst1, yHst2, yHst3 and yHst4p, and sustained H3K56 hyperacetylation impedes the completion of DNA repair and increases cell sensitivity to DNA-damaging agents (Celic et al., 2006; Das et al., 2009; Maas et al., 2006; Miller et al., 2010; Vempati et al., 2010). In general, histone acetylation is dynamically regulated during DNA repair, and the balance between histone acetyltransferases and histone deacetylases is critical for the repair process and genome integrity.

\section{UBIQUITINATION}

Ubiquitination is a complicated process, in which the conserved 76-residue polypeptide ubiquitin is covalently conjugated to the $\varepsilon$-amino group of a substrate lysine residue (Komander, 2009). It requires the sequential actions of three enzymes: an E1 activating enzyme that forms a thiol ester with the carboxyl group of G76, an E2 conjugating enzyme that transiently carries the activated ubiquitin molecule as a thiol ester and an E3 ligase that transfers the activated ubiquitin from the E2 to the substrate (or ubiquitin) lysine residue (Pickart, 2001). Ubiquitination regulates many critical cellular functions, mainly by ubiquitin-dependent degradation of substrates, while histone ubiquitination regulates a broad range of DNA related processes (Bennett and Harper, 2008; Cao and Yan, 2012). For example, histone H2B ubiquitynation interferes with chromatin compaction and leads to an open and biochemically accessible fiber conformation (Fierz et al., 2011). However, another study showed that H2A ubiquitynation prevents RNA polymerase II elongation-dependent chromatin decondensation, and induces transcriptional silencing at regions distal to DSBs (double-strand breaks) (Shanbhag et al., 2010). Nevertheless, histone ubiquitynation is capable of modulating chromatin structure, transcription and DNA damage response. The indispensable role of histone ubiquitynation in DNA damage response has been well-recognized nowadays (Messick and Greenberg, 2009).

The first important ubiquitination event in DNA damage response is RNF8/RNF168-mediated histone ubiquitination. Upon DNA double-strand break or UV radiation, MDC1 recruits RNF8 through phosphodependent interactions between the RNF8 forkhead-associated domain and motifs in MDC1 that are phosphorylated by ATM (Kolas et al., 2007; Mailand et al., 2007; Marteijn et al., 2009). The E3 ligase activity of RNF8 is required for the formation of lysine 63-linked ubiquitin chains at damage sites to induce the recruitment of another E3 ligase RNF168, by its ubiquitin binding domains (Doil et al., 2009; Stewart et al., 2009). RNF168 binds and amplifies ubiquitin conjugates on damaged chromosomes (Campbell et al., 2012; Doil et al., 2009; Wang and Elledge, 2007; Wu et al., 2009). MDC1-mediated and RNF8/RNF168-excuted ubiquitination occurs at K15 on $\mathrm{H} 2 \mathrm{~A} / \mathrm{H} 2 \mathrm{AX}$, and ubK15 is directly recognized by 53BP1 (Fradet-Turcotte et al., 2013; Mattiroli et al., 2012). RNF8 or RNF168 deficient cells display impaired cellular responses to DNA damage, a defective G2/M checkpoint and increased radiosensitivity (Doil et al., 2009; Huen et al., 2007). In addition to K63 linked ubiquitination, RNF168 promotes noncanonical $\mathrm{K} 27$ linked ubiquitination in vivo and in vitro, and this specific ubiquitination is also required for the proper activation of the DNA damage response (Gatti et al., 2015). Additionally, the polycomb repressive complex 1, which contains Bmi1, Ring1, and Ring2, is required for $\mathrm{H} 2 \mathrm{~A} / \mathrm{H} 2 \mathrm{AX}$ ubiquitination (Bergink et al., 2006; Cao et al., 2005). Although the role of Ring1-mediated H2A ubiquitination in DNA damage response is not clear, Bmil and Ring2 are recruited to sites of DNA damage where they contribute to the monoubiquitylation of $\mathrm{H} 2 \mathrm{~A} / \mathrm{H} 2 \mathrm{AX}$ at Lys119/Lys120 (Ginjala et al., 2011; Pan et al., 2011). Bmi1/Ring2-dependent $\mathrm{H} 2 \mathrm{~A} / \mathrm{H} 2 \mathrm{AX}$ ubiquitination is critical for the localization of 53BP1, BRCA1 and other repair factors (Facchino et al., 2010; Ismail et al., 2010). Consequently, loss of Bim1 or Ring2 leads to impaired repair of double-strand break, G2/M cell cycle arrest and increased cellular sensitivity to irradiation or genotoxic agents (Chagraoui et al., 2011; Ginjala et al., 2011). However, the relationship between $\mathrm{H} 2 \mathrm{~A} / \mathrm{H} 2 \mathrm{AX}$ ubiquitination and $\gamma \mathrm{H} 2 \mathrm{AX}$ is not clear. Moreover, some other ubiquitin E3 ligases, such as B-lymphoma and BAL-associated protein (BBAP) (Yan et al., 2009), RNF20-RNF40 heterodimer (Moyal et al., 2011; Nakamura et al., 2011), Cul4-DDBRoc1 (Wang et al., 2006) and checkpoint with forkheadassociated (FHA) and RING finger domain protein (CHFR) (Liu et al., 2013), have been shown to be involved in his- 
tone ubiquitination in response to DNA damage as well.

Histone ubiquitination is tightly regulated during the cellular response to DNA damage. Firstly, some deubiquitinases are involved in the removal of histone ubiquitination. For instance, the deubiquitinating enzyme OTUB2 suppresses RNF8-mediated Lys 63-linked ubiquitin chain formation in a deubiquitinating activity-dependent manner. Depletion of OTUB2 enhances RNF8-mediated ubiquitination in an early phase of the DNA damage response, favors the accelerated accumulation of 53BP1 and RAP80 at DSBs, thus promoting DSB repair by NHEJ (Kato et al., 2014). Therefore, OTUB2 fine-tunes the speed of RNF8mediated ubiquitination so that the appropriate DNA repair pathway is chosen. In addition to OTUB2, other deubiquitinases, such as usp44 (Mosbech et al., 2013), Dub3 (Delgado-Diaz et al., 2014) and BAP1 (Yu et al., 2014), are responsible for the $\mathrm{H} 2 \mathrm{~A} / \mathrm{H} 2 \mathrm{AX}$ deubiquitination as well. They might act in concert with the ubiquitin E3 ligases, such as RNF8/RNF168 and the PRC1 complex, to promote the dynamic ubiquitination/deubiquitination of histones at DNA damage sites. Next, it has been demonstrated that RNF169, an E3 ubiquitin ligase paralogous to RNF168, accumulates at DNA damage foci through direct recognition of RNF168-mediated histone ubiquitylation. Therefore, RNF169 functionally competes with 53BP1 for association with ubiquitinated histones, and impairs the 53BP1 recruitment at sites of DNA damage, resulting in stimulated HR and restrained NHEJ (Chen et al., 2012; Poulsen et al., 2012). Moreover, p400 SWI/SNF ATPase and HERC2 are required for RNF8/RNF168-mediated ubiquitination, either by destabilization of nucleosomes or by facilitating the assembly of the ubiquitin-conjugating enzyme Ubc13 with RNF8 (Bekker-Jensen et al., 2010; Xu et al., 2010).

\section{OTHERS}

Many other histone modifications are reported to influence DNA damage response. At first, the ubiquitin-like protein NEDD8 accumulates at DNA damage sites in an E3 ligase RNF111-dependent manner, and $\mathrm{H} 4$ is polyneddylated at the N-terminal lysine residues. $\mathrm{H} 4$ neddylation can be recognized by RNF168, and loss of H4 neddylation impairs the localization of RNF168 and its downstream functional partners, such as 53BP1 and BRCA1, thus affecting the process of DNA repair (Ma et al., 2013). In addition, the histone variant H2A.Z, and its SUMO modification, is required for DNA resection, single DSB-induced checkpoint activation, and DSB anchoring to the nuclear periphery (Kalocsay et al., 2009). Moreover, it has been demonstrated in many studies that histones are covalently modified by mono(ADP)-ribose in response to DNA single-strand break (Adamietz and Rudolph, 1984; Bohm et al., 1997; Kreimeyer et al., 1984). TbSIR2RP1, a SIR2-related protein from the protozoan parasite Trypanosoma brucei, has been shown to catalyze the mono(ADP)-ribosylation of histones, partic- ulary $\mathrm{H} 2 \mathrm{~A}$ and $\mathrm{H} 2 \mathrm{~B}$, and treatment of trypanosomal nuclei with a DNA alkylating agent results in a significant increase in the level of histone H2A/H2B ADP-ribosylation. Consequently, depletion of TbSIR2RP1 decreased the cellular resistance to DNA damage (Garcia-Salcedo et al., 2003). However, histone ADP-ribosylation occurs only upon DNA single-srand break, and its role in double-strand break repair is not clear now.

\section{CROSSTALKS AMONG HISTONE MODIFICATIONS}

There are various crosstalks among different modifications. At first, some modifications such as $\gamma \mathrm{H} 2 \mathrm{AX}$ can serve as a platform for other modification factors, and promote the formation of some other modifications. In addition, some modifications can cooperate with each other to promote DNA repair. For example, both $\mathrm{H} 3 \mathrm{~K} 36 \mathrm{me} 2$ and H3K36me3 can promote HR, while both H3K79 methylation and H4K20 methylation are capable of recruiting 53BP1. In the future, with an increasing understanding of the process of DNA damage response, much more crosstalks will be discovered.

\section{CONCLUSION AND FUTURE DIRECTIONS}

Histones are the major protein components of chromatin and are subject to many posttranslational modifications, especially on their $\mathrm{N}$-terminals. These modifications may constitute a "histone code" to modulate many cellular processes, such as DNA damage response. DNA damage response is a complicated process, in which many factors are involved, in order to repair the damaged DNA and maintain the genome stability. Although the kinetics of DNA damage response has been extensively studied, the exact order of histone modifications and other repair factors remains imprecise. It seems that many histone modifications regulate each other's formation and accumulation, and the intricate crosstalk among these modifications renders the study of the specific function of a single histone modification more difficult. However, it is clear that the timing of histone modifications is critical for the chromatin dynamics in the DNA damage response and efficient DNA repair. Therefore, it is still essential to clarify the exact role of each histone modification in DNA damage response in future studies. In addition, a lot of new histone modifications have been described recent years, and the functions of these modifications in DNA damage response are not clear. It is interesting to identify new histone modifications that are involved in DNA damage response in the future.

Considering the importance of histone modifications in DNA damage response, they may serve as targets for small molecules to interfere DNA repair to increase the radiosen- 
sitivity or chemosensitivity of cancer cells. Actually, HDAC inhibitors have already been shown to alter tumor radiosensitivity through the modulation of histone acetylation and have been used in cancer treatment (Camphausen and Tofilon, 2007). In the future, it is of great value to develop drugs targeting histone methylation, ubiquitination and other histone modifications. Based on the basic research, it is promising to cure cancer via combination therapy, which contributes to DNA damage and histone modification interference.

Compliance and ethics The author(s) declare that they have no conflict of interest.

Acknowledgements We sincerely apologize for unable to include many other valuable papers in this review due to the space limitation. We sincerely appreciate the helpful advices provided by other members of our group during the writing of this review. The work was supported by the National Natural Science Foundation of China (81321003, 91319302, 31070691), Ministry of Science and Technology of China (2011CB504200), Ministry of Education of China (111 project) and Peking University-Tsinghua University Center for Life Science.

Adamietz, P., and Rudolph, A. (1984). ADP-ribosylation of nuclear proteins in vivo. Identification of histone $\mathrm{H} 2 \mathrm{~B}$ as a major acceptor for mono- and poly(ADP-ribose) in dimethyl sulfate-treated hepatoma $\mathrm{AH}$ 7974 cells. J Biol Chem 259, 6841-6846.

Arnaudo, A.M., and Garcia, B.A. (2013). Proteomic characterization of novel histone post-translational modifications. Epigenet Chromat 6, 24.

Ayoub, N., Jeyasekharan, A.D., Bernal, J.A., and Venkitaraman, A.R. (2008). HP1-beta mobilization promotes chromatin changes that initiate the DNA damage response. Nature 453, 682-686.

Ayrapetov, M.K., Gursoy-Yuzugullu, O., Xu, C., Xu, Y., and Price, B.D. (2014). DNA double-strand breaks promote methylation of histone H3 on lysine 9 and transient formation of repressive chromatin. Proc Natl Acad Sci USA 111, 9169-9174.

Bannister, A.J., and Kouzarides, T. (2011). Regulation of chromatin by histone modifications. Cell Res 21, 381-395.

Bassing, C.H., Chua, K.F., Sekiguchi, J., Suh, H., Whitlow, S.R., Fleming, J.C., Monroe, B.C., Ciccone, D.N., Yan, C., Vlasakova, K., Livingston, D.M., Ferguson, D.O., Scully, R., and Alt, F.W. (2002). Increased ionizing radiation sensitivity and genomic instability in the absence of histone H2AX. Proc Natl Acad Sci USA 99, 8173-8178.

Bassing, C.H., Suh, H., Ferguson, D.O., Chua, K.F., Manis, J., Eckersdorff, M., Gleason, M., Bronson, R., Lee, C., and Alt, F.W. (2003). Histone H2AX: a dosage-dependent suppressor of oncogenic translocations and tumors. Cell 114, 359-370.

Battu, A., Ray, A., and Wani, A.A. (2011). ASF1A and ATM regulate H3K56-mediated cell-cycle checkpoint recovery in response to UV irradiation. Nucleic Acids Res 39, 7931-7945.

Bekker-Jensen, S., Rendtlew Danielsen, J., Fugger, K., Gromova, I., Nerstedt, A., Lukas, C., Bartek, J., Lukas, J., and Mailand, N. (2010). HERC2 coordinates ubiquitin-dependent assembly of DNA repair factors on damaged chromosomes. Nat Cell Biol 12, 80-86; sup pp $81-12$.

Bennett, E.J., and Harper, J.W. (2008). DNA damage: ubiquitin marks the spot. Nat Struct Mol Biol 15, 20-22.

Bergink, S., Salomons, F.A., Hoogstraten, D., Groothuis, T.A., de Waard, H., Wu, J., Yuan, L., Citterio, E., Houtsmuller, A.B., Neefjes, J., Hoeijmakers, J.H., Vermeulen, W., and Dantuma, N.P. (2006). DNA damage triggers nucleotide excision repair-dependent monoubiquitylation of histone H2A. Genes Dev 20, 1343-1352.

Bhaskara, S., Chyla, B.J., Amann, J.M., Knutson, S.K., Cortez, D., Sun,
Z.W., and Hiebert, S.W. (2008). Deletion of histone deacetylase 3 reveals critical roles in $\mathrm{S}$ phase progression and DNA damage control. Mol Cell 30, 61-72.

Bird, A.W., Yu, D.Y., Pray-Grant, M.G., Qiu, Q., Harmon, K.E., Megee, P.C., Grant, P.A., Smith, M.M., and Christman, M.F. (2002). Acetylation of histone $\mathrm{H} 4$ by Esa1 is required for DNA double-strand break repair. Nature 419, 411-415.

Bohm, L., Schneeweiss, F.A., Sharan, R.N., and Feinendegen, L.E. (1997). Influence of histone acetylation on the modification of cytoplasmic and nuclear proteins by ADP-ribosylation in response to free radicals. Biochim Biophys Acta 1334, 149-154.

Bonner, W.M., Redon, C.E., Dickey, J.S., Nakamura, A.J., Sedelnikova, O.A., Solier, S., and Pommier, Y. (2008). GammaH2AX and cancer. Nat Rev Cancer 8, 957-967.

Botuyan, M.V., Lee, J., Ward, I.M., Kim, J.E., Thompson, J.R., Chen, J., and Mer, G. (2006). Structural basis for the methylation state-specific recognition of histone $\mathrm{H} 4-\mathrm{K} 20$ by $53 \mathrm{BP} 1$ and $\mathrm{Crb} 2$ in DNA repair. Cell 127, 1361-1373.

Campbell, S., Ismail, I.H., Young, L.C., Poirier, G.G., and Hendzel, M.J. (2013). Polycomb repressive complex 2 contributes to DNA double-strand break repair. Cell Cycle 12, 2675-2683.

Campbell, S.J., Edwards, R.A., Leung, C.C., Neculai, D., Hodge, C.D., Dhe-Paganon, S., and Glover, J.N. (2012). Molecular insights into the function of RING finger (RNF)-containing proteins hRNF8 and hRNF168 in Ubc13/Mms2-dependent ubiquitylation. J Biol Chem 287, 23900-23910.

Camphausen, K., and Tofilon, P.J. (2007). Inhibition of histone deacetylation: a strategy for tumor radiosensitization. J Clin Oncol 25, 4051-4056.

Campos, E.I., and Reinberg, D. (2009). Histones: annotating chromatin. Annu Rev Genet 43, 559-599.

Cao, J., and Yan, Q. (2012). Histone ubiquitination and deubiquitination in transcription, DNA damage response, and cancer. Front Oncol 2, 26.

Cao, L.L., Wei, F., Du, Y., Song, B., Wang, D., Shen, C., Lu, X., Cao, Z., Yang, Q., Gao, Y., Wang, L., Zhao, Y., Wang, H., Yang, Y., and Zhu, W.G. (2015). ATM-mediated KDM2A phosphorylation is required for the DNA damage repair. Oncogene doi: 10.1038/onc.2015.81.

Cao, R., Tsukada, Y., and Zhang, Y. (2005). Role of Bmi-1 and Ring1A in H2A ubiquitylation and Hox gene silencing. Mol Cell 20, 845-854.

Celeste, A., Difilippantonio, S., Difilippantonio, M.J., Fernandez-Capetillo, O., Pilch, D.R., Sedelnikova, O.A., Eckhaus, M., Ried, T., Bonner, W.M., and Nussenzweig, A. (2003a). H2AX haploinsufficiency modifies genomic stability and tumor susceptibility. Cell 114, 371-383.

Celeste, A., Fernandez-Capetillo, O., Kruhlak, M.J., Pilch, D.R., Staudt, D.W., Lee, A., Bonner, R.F., Bonner, W.M., and Nussenzweig, A. (2003b). Histone H2AX phosphorylation is dispensable for the initial recognition of DNA breaks. Nat Cell Biol 5, 675-679.

Celeste., A., Petersen., S., Romanienko., P.J., Fernandez-Capetillo., O., Chen., H.T., Sedelnikova., O.A., Reina-San-Martin., B., Coppola., V., Meffre., E., DiPlippantonio., M.J., Redon., C., Pilch., D.R., Olaru., A., Eckhaus., M., Camerini-Otero., R.D., Tessarollo., L., Livak., F., Manova., K., Bonner., W.M., Nussenzweig., M.C., and Nussenzweig., A. (2002). Genomic instability in mice lacking histone H2AX. Science 296, 922-927.

Celic, I., Masumoto, H., Griffith, W.P., Meluh, P., Cotter, R.J., Boeke, J.D., and Verreault, A. (2006). The sirtuins hst3 and Hst4p preserve genome integrity by controlling histone h3 lysine 56 deacetylation. Curr Biol 16, 1280-1289.

Chagraoui, J., Hebert, J., Girard, S., and Sauvageau, G. (2011). An anticlastogenic function for the Polycomb Group gene Bmil. Proc Natl Acad Sci USA 108, 5284-5289.

Chaudhuri, S., Wyrick, J.J., and Smerdon, M.J. (2009). Histone H3 Lys79 methylation is required for efficient nucleotide excision repair in a silenced locus of Saccharomyces cerevisiae. Nucleic Acids Res 37, 1690-1700.

Chen, C.C., Carson, J.J., Feser, J., Tamburini, B., Zabaronick, S., Linger, J., and Tyler, J.K. (2008). Acetylated lysine 56 on histone H3 drives chromatin assembly after repair and signals for the completion of repair. Cell 134, 231-243. 
Chen, J., Feng, W., Jiang, J., Deng, Y., and Huen, M.S. (2012). Ring finger protein RNF169 antagonizes the ubiquitin-dependent signaling cascade at sites of DNA damage. J Biol Chem 287, 27715-27722.

Cheung, W.L., Ajiro, K., Samejima, K., Kloc, M., Cheung, P., Mizzen, C.A., Beeser, A., Etkin, L.D., Chernoff, J., Earnshaw, W.C., and Allis, C.D. (2003). Apoptotic phosphorylation of histone H2B is mediated by mammalian sterile twenty kinase. Cell 113, 507-517.

Cheung, W.L., Turner, F.B., Krishnamoorthy, T., Wolner, B., Ahn, S.H., Foley, M., Dorsey, J.A., Peterson, C.L., Berger, S.L., and Allis, C.D. (2005). Phosphorylation of histone H4 serine 1 during DNA damage requires casein kinase II in S. cerevisiae. Curr Biol 15, 656-660.

Chou, D.M., Adamson, B., Dephoure, N.E., Tan, X., Nottke, A.C., Hurov, K.E., Gygi, S.P., Colaiacovo, M.P., and Elledge, S.J. (2010). A chromatin localization screen reveals poly (ADP ribose)-regulated recruitment of the repressive polycomb and NuRD complexes to sites of DNA damage. Proc Natl Acad Sci USA 107, 18475-18480.

Chowdhury, D., Keogh, M.C., Ishii, H., Peterson, C.L., Buratowski, S., and Lieberman, J. (2005). gamma-H2AX dephosphorylation by protein phosphatase 2A facilitates DNA double-strand break repair. Mol Cell 20, 801-809.

Chowdhury, D., Xu, X., Zhong, X., Ahmed, F., Zhong, J., Liao, J., Dykxhoorn, D.M., Weinstock, D.M., Pfeifer, G.P., and Lieberman, J. (2008). A PP4-phosphatase complex dephosphorylates gamma-H2AX generated during DNA replication. Mol Cell 31, 33-46.

Ciccia, A., and Elledge, S.J. (2010). The DNA damage response: making it safe to play with knives. Mol Cell 40, 179-204.

Conde, F., Refolio, E., Cordon-Preciado, V., Cortes-Ledesma, F., Aragon, L., Aguilera, A., and San-Segundo, P.A. (2009). The Dot1 histone methyltransferase and the $\operatorname{Rad} 9$ checkpoint adaptor contribute to cohesin-dependent double-strand break repair by sister chromatid recombination in Saccharomyces cerevisiae. Genetics 182, 437-446.

Cook, P.J., Ju, B.G., Telese, F., Wang, X., Glass, C.K., and Rosenfeld, M.G. (2009). Tyrosine dephosphorylation of H2AX modulates apoptosis and survival decisions. Nature 458, 591-596.

Dai, L., Peng, C., Montellier, E., Lu, Z., Chen, Y., Ishii, H., Debernardi, A., Buchou, T., Rousseaux, S., Jin, F., Sabari, B.R., Deng, Z., Allis, C.D., Ren, B., Khochbin, S., and Zhao, Y. (2014). Lysine 2-hydroxyisobutyrylation is a widely distributed active histone mark. Nat Chem Biol 10, 365-370.

Das, C., Lucia, M.S., Hansen, K.C., and Tyler, J.K. (2009). $\mathrm{CBP} / \mathrm{p} 300$-mediated acetylation of histone H3 on lysine 56 . Nature 459 , 113-117.

Delgado-Diaz, M.R., Martin, Y., Berg, A., Freire, R., and Smits, V.A. (2014). Dub3 controls DNA damage signalling by direct deubiquitination of H2AX. Mol Oncol 8, 884-893.

Doil, C., Mailand, N., Bekker-Jensen, S., Menard, P., Larsen, D.H., Pepperkok, R., Ellenberg, J., Panier, S., Durocher, D., Bartek, J., Lukas, J., and Lukas, C. (2009). RNF168 binds and amplifies ubiquitin conjugates on damaged chromosomes to allow accumulation of repair proteins. Cell 136, 435-446.

Douglas, P., Zhong, J., Ye, R., Moorhead, G.B., Xu, X., and Lees-Miller, S.P. (2010). Protein phosphatase 6 interacts with the DNA-dependent protein kinase catalytic subunit and dephosphorylates gamma-H2AX. Mol Cell Biol 30, 1368-1381.

Downs, J.A., Allard, S., Jobin-Robitaille, O., Javaheri, A., Auger, A., Bouchard, N., Kron, S.J., Jackson, S.P., and Cote, J. (2004). Binding of chromatin-modifying activities to phosphorylated histone H2A at DNA damage sites. Mol Cell 16, 979-990.

Downs, J.A., Lowndes, N.F., and Jackson, S.P. (2000). A role for Saccharomyces cerevisiae histone H2A in DNA repair. Nature 408, 1001-1004.

Driscoll, R., Hudson, A., and Jackson, S.P. (2007). Yeast Rtt109 promotes genome stability by acetylating histone $\mathrm{H} 3$ on lysine 56 . Science 315 , 649-652.

Dulev, S., Tkach, J., Lin, S., and Batada, N.N. (2014). SET8 methyltransferase activity during the DNA double-strand break response is required for recruitment of 53BP1. EMBO Rep 15, 1163-1174.

Facchino, S., Abdouh, M., Chatoo, W., and Bernier, G. (2010). BMI1 confers radioresistance to normal and cancerous neural stem cells through recruitment of the DNA damage response machinery. J Neurosci 30, 10096-10111.

Faucher, D., and Wellinger, R.J. (2010). Methylated H3K4, a transcription-associated histone modification, is involved in the DNA damage response pathway. PLoS Genet doi: 10.1371/journal. pgen.1001082.

Fernandez-Capetillo, O., Allis, C.D., and Nussenzweig, A. (2004). Phosphorylation of histone H2B at DNA double-strand breaks. J Exp Med 199, 1671-1677.

Fierz, B., Chatterjee, C., McGinty, R.K., Bar-Dagan, M., Raleigh, D.P., and Muir, T.W. (2011). Histone H2B ubiquitylation disrupts local and higher-order chromatin compaction. Nat Chem Biol 7, 113-119.

Fink, M., Imholz, D., and Thoma, F. (2007). Contribution of the serine 129 of histone H2A to chromatin structure. Mol Cell Biol 27, 3589-3600.

Fnu, S., Williamson, E.A., De Haro, L.P., Brenneman, M., Wray, J., Shaheen, M., Radhakrishnan, K., Lee, S.H., Nickoloff, J.A., and Hromas, R. (2011). Methylation of histone H3 lysine 36 enhances DNA repair by nonhomologous end-joining. Proc Natl Acad Sci USA 108, $540-545$.

Fradet-Turcotte, A., Canny, M.D., Escribano-Diaz, C., Orthwein, A., Leung, C.C., Huang, H., Landry, M.C., Kitevski-LeBlanc, J., Noordermeer, S.M., Sicheri, F., and Durocher, D. (2013). 53BP1 is a reader of the DNA-damage-induced H2A Lys 15 ubiquitin mark. Nature 499, 50-54.

Garcia-Salcedo, J.A., Gijon, P., Nolan, D.P., Tebabi, P., and Pays, E. (2003). A chromosomal SIR2 homologue with both histone NAD-dependent ADP-ribosyltransferase and deacetylase activities is involved in DNA repair in Trypanosoma brucei. EMBO J 22, 5851-5862.

Gatti, M., Pinato, S., Maiolica, A., Rocchio, F., Prato, M.G., Aebersold, R., and Penengo, L. (2015). RNF168 promotes noncanonical K27 ubiquitination to signal DNA damage. Cell Rep 10, 226-238.

Giannattasio, M., Lazzaro, F., Plevani, P., and Muzi-Falconi, M. (2005). The DNA damage checkpoint response requires histone H2B ubiquitination by Rad6-Bre1 and H3 methylation by Dot1. J Biol Chem 280, 9879-9886.

Ginjala, V., Nacerddine, K., Kulkarni, A., Oza, J., Hill, S.J., Yao, M., Citterio, E., van Lohuizen, M., and Ganesan, S. (2011). BMI1 is recruited to DNA breaks and contributes to DNA damage-induced H2A ubiquitination and repair. Mol Cell Biol 31, 1972-1982.

Greeson, N.T., Sengupta, R., Arida, A.R., Jenuwein, T., and Sanders, S.L. (2008). Di-methyl H4 lysine 20 targets the checkpoint protein Crb2 to sites of DNA damage. J Biol Chem 283, 33168-33174.

Grewal, S.I., and Jia, S. (2007). Heterochromatin revisited. Nat Rev Genet $8,35-46$.

Grunstein, M. (1997). Histone acetylation in chromatin structure and transcription. Nature 389, 349-352.

Guo, R., Chen, J., Mitchell, D.L., and Johnson, D.G. (2011). GCN5 and E2F1 stimulate nucleotide excision repair by promoting $\mathrm{H} 3 \mathrm{~K} 9$ acetylation at sites of damage. Nucleic Acids Res 39, 1390-1397.

Gupta, A., Sharma, G.G., Young, C.S., Agarwal, M., Smith, E.R., Paull, T.T., Lucchesi, J.C., Khanna, K.K., Ludwig, T., and Pandita, T.K. (2005). Involvement of human MOF in ATM function. Mol Cell Biol $25,5292-5305$

Gyorgy, B., Toth, E., Tarcsa, E., Falus, A., and Buzas, E.I. (2006). Citrullination: a posttranslational modification in health and disease. Int J Biochem Cell Biol 38, 1662-1677.

Hajdu, I., Ciccia, A., Lewis, S.M., and Elledge, S.J. (2011). Wolf-Hirschhorn syndrome candidate 1 is involved in the cellular response to DNA damage. Proc Natl Acad Sci USA 108, 13130-13134.

Han, J., Zhou, H., Horazdovsky, B., Zhang, K., Xu, R.M., and Zhang, Z. (2007). Rtt109 acetylates histone H3 lysine 56 and functions in DNA replication. Science 315, 653-655.

House, N.C., Yang, J.H., Walsh, S.C., Moy, J.M., and Freudenreich, C.H. (2014). NuA4 initiates dynamic histone $\mathrm{H} 4$ acetylation to promote high-fidelity sister chromatid recombination at postreplication gaps. Mol Cell 55, 818-828.

Hromas, R., Williamson, E.A., Fnu, S., Lee, Y.J., Park, S.J., Beck, B.D., 
You, J.S., Leitao, A., Nickoloff, J.A., and Lee, S.H. (2012). Chk1 phosphorylation of Metnase enhances DNA repair but inhibits replication fork restart. Oncogene 31, 4245-4254.

Hsiao, K.Y., and Mizzen, C.A. (2013). Histone H4 deacetylation facilitates 53BP1 DNA damage signaling and double-strand break repair. J Mol Cell Biol 5, 157-165.

Huen, M.S., Grant, R., Manke, I., Minn, K., Yu, X., Yaffe, M.B., and Chen, J. (2007). RNF8 transduces the DNA-damage signal via histone ubiquitylation and checkpoint protein assembly. Cell 131, 901-914.

Huyen, Y., Zgheib, O., Ditullio, R.A., Jr., Gorgoulis, V.G., Zacharatos, P., Petty, T.J., Sheston, E.A., Mellert, H.S., Stavridi, E.S., and Halazonetis, T.D. (2004). Methylated lysine 79 of histone H3 targets 53BP1 to DNA double-strand breaks. Nature 432, 406-411.

Iacovoni, J.S., Caron, P., Lassadi, I., Nicolas, E., Massip, L., Trouche, D., and Legube, G. (2010). High-resolution profiling of gammaH2AX around DNA double strand breaks in the mammalian genome. EMBO J 29, 1446-1457.

Ikura, T., Ogryzko, V.V., Grigoriev, M., Groisman, R., Wang, J., Horikoshi, M., Scully, R., Qin, J., and Nakatani, Y. (2000). Involvement of the TIP60 histone acetylase complex in DNA repair and apoptosis. Cell 102, 463-473.

Ismail, I.H., Andrin, C., McDonald, D., and Hendzel, M.J. (2010). BMI1-mediated histone ubiquitylation promotes DNA double-strand break repair. J Cell Biol 191, 45-60.

Jackson, S.P., and Bartek, J. (2009). The DNA-damage response in human biology and disease. Nature 461, 1071-1078.

Javaheri, A., Wysocki, R., Jobin-Robitaille, O., Altaf, M., Cote, J., and Kron, S.J. (2006). Yeast G1 DNA damage checkpoint regulation by $\mathrm{H} 2 \mathrm{~A}$ phosphorylation is independent of chromatin remodeling. Proc Natl Acad Sci USA 103, 13771-13776.

Jazayeri, A., McAinsh, A.D., and Jackson, S.P. (2004). Saccharomyces cerevisiae $\operatorname{Sin} 3$ p facilitates DNA double-strand break repair. Proc Natl Acad Sci USA 101, 1644-1649.

Jha, D.K., and Strahl, B.D. (2014). An RNA polymerase II-coupled function for histone H3K36 methylation in checkpoint activation and DSB repair. Nat Commun 5, 3965.

Jones, B., Su, H., Bhat, A., Lei, H., Bajko, J., Hevi, S., Baltus, G.A., Kadam, S., Zhai, H., Valdez, R., Gonzalo, S., Zhang, Y., Li, E., and Chen, T. (2008). The histone H3K79 methyltransferase Dot1L is essential for mammalian development and heterochromatin structure. PLoS Genet 4, e1000190.

Kalocsay, M., Hiller, N.J., and Jentsch, S. (2009). Chromosome-wide Rad51 spreading and SUMO-H2A.Z-dependent chromosome fixation in response to a persistent DNA double-strand break. Mol Cell 33, 335-343.

Kato, K., Nakajima, K., Ui, A., Muto-Terao, Y., Ogiwara, H., and Nakada, S. (2014). Fine-tuning of DNA damage-dependent ubiquitination by OTUB2 supports the DNA repair pathway choice. Mol Cell 53, 617-630

Keogh, M.C., Kim, J.A., Downey, M., Fillingham, J., Chowdhury, D., Harrison, J.C., Onishi, M., Datta, N., Galicia, S., Emili, A., Lieberman, J., Shen, X., Buratowski, S., Haber, J.E., Durocher, D., Greenblatt, J.F., and Krogan, N.J. (2006). A phosphatase complex that dephosphorylates gammaH2AX regulates DNA damage checkpoint recovery. Nature 439, 497-501.

Khoury-Haddad, H., Guttmann-Raviv, N., Ipenberg, I., Huggins, D., Jeyasekharan, A.D., and Ayoub, N. (2014). PARP1-dependent recruitment of KDM4D histone demethylase to DNA damage sites promotes double-strand break repair. Proc Natl Acad Sci USA 111, E728-E737.

Kim, J.A., Kruhlak, M., Dotiwala, F., Nussenzweig, A., and Haber, J.E. (2007). Heterochromatin is refractory to gamma-H2AX modification in yeast and mammals. J Cell Biol 178, 209-218.

Kolas, N.K., Chapman, J.R., Nakada, S., Ylanko, J., Chahwan, R., Sweeney, F.D., Panier, S., Mendez, M., Wildenhain, J., Thomson, T.M., Pelletier, L., Jackson, S.P., and Durocher, D. (2007). Orchestration of the DNA-damage response by the RNF8 ubiquitin ligase. Science 318, 1637-1640.

Komander, D. (2009). The emerging complexity of protein ubiquitination.
Biochem Soc Trans 37, 937-953.

Kouzarides, T. (2000). Acetylation: a regulatory modification to rival phosphorylation? EMBO J 19, 1176-1179.

Kouzarides, T. (2007). Chromatin modifications and their function. Cell $128,693-705$.

Kreimeyer, A., Wielckens, K., Adamietz, P., and Hilz, H. (1984). DNA repair-associated ADP-ribosylation in vivo. Modification of histone H1 differs from that of the principal acceptor proteins. J Biol Chem 259, 890-896.

Kusch, T., Florens, L., Macdonald, W.H., Swanson, S.K., Glaser, R.L., Yates, J.R., 3rd, Abmayr, S.M., Washburn, M.P., and Workman, J.L. (2004). Acetylation by Tip60 is required for selective histone variant exchange at DNA lesions. Science 306, 2084-2087.

Lee, H.S., Park, J.H., Kim, S.J., Kwon, S.J., and Kwon, J. (2010a). A cooperative activation loop among SWI/SNF, gamma-H2AX and $\mathrm{H} 3$ acetylation for DNA double-strand break repair. EMBO J 29, 1434-1445.

Lee, J.S., Smith, E., and Shilatifard, A. (2010b). The language of histone crosstalk. Cell 142, 682-685.

Lee, S.H., Oshige, M., Durant, S.T., Rasila, K.K., Williamson, E.A., Ramsey, H., Kwan, L., Nickoloff, J.A., and Hromas, R. (2005). The SET domain protein Metnase mediates foreign DNA integration and links integration to nonhomologous end-joining repair. Proc Natl Acad Sci USA 102, 18075-18080.

Li, F., Mao, G., Tong, D., Huang, J., Gu, L., Yang, W., and Li, G.M. (2013). The histone mark H3K36me3 regulates human DNA mismatch repair through its interaction with MutSalpha. Cell 153, 590-600.

Li, X., Corsa, C.A., Pan, P.W., Wu, L., Ferguson, D., Yu, X., Min, J., and Dou, Y. (2010). MOF and H4 K16 acetylation play important roles in DNA damage repair by modulating recruitment of DNA damage repair protein Mdc1. Mol Cell Biol 30, 5335-5347.

Li, X., Liu, L., Yang, S., Song, N., Zhou, X., Gao, J., Yu, N., Shan, L., Wang, Q., Liang, J., Xuan, C., Wang, Y., Shang, Y., and Shi, L. (2014). Histone demethylase KDM5B is a key regulator of genome stability. Proc Natl Acad Sci USA 111, 7096-7101.

Liang, C.Y., Hsu, P.H., Chou, D.F., Pan, C.Y., Wang, L.C., Huang, W.C., Tsai, M.D., and Lo, W.S. (2011). The histone H3K36 demethylase Rph1/KDM4 regulates the expression of the photoreactivation gene PHR1. Nucleic Acids Res 39, 4151-4165.

Liang, C.Y., Wang, L.C., and Lo, W.S. (2013). Dissociation of the H3K36 demethylase Rph1 from chromatin mediates derepression of environmental stress-response genes under genotoxic stress in Saccharomyces cerevisiae. Mol Biol Cell 24, 3251-3262.

Liu, C., Wu, J., Paudyal, S.C., You, Z., and Yu, X. (2013). CHFR is important for the first wave of ubiquitination at DNA damage sites. Nucleic Acids Res 41, 1698-1710.

Lord, C.J., and Ashworth, A. (2012). The DNA damage response and cancer therapy. Nature 481, 287-294.

Ma, T., Chen, Y., Zhang, F., Yang, C.Y., Wang, S., and Yu, X. (2013). RNF111-dependent neddylation activates DNA damage-induced ubiquitination. Mol Cell 49, 897-907.

Maas, N.L., Miller, K.M., DeFazio, L.G., and Toczyski, D.P. (2006). Cell cycle and checkpoint regulation of histone H3 K56 acetylation by Hst3 and Hst4. Mol Cell 23, 109-119.

Macurek, L., Lindqvist, A., Voets, O., Kool, J., Vos, H.R., and Medema, R.H. (2010). Wip1 phosphatase is associated with chromatin and dephosphorylates gammaH2AX to promote checkpoint inhibition. Oncogene 29, 2281-2291.

Mah, L.J., El-Osta, A., and Karagiannis, T.C. (2010). gammaH2AX: a sensitive molecular marker of DNA damage and repair. Leukemia 24 , 679-686.

Mailand, N., Bekker-Jensen, S., Faustrup, H., Melander, F., Bartek, J., Lukas, C., and Lukas, J. (2007). RNF8 ubiquitylates histones at DNA double-strand breaks and promotes assembly of repair proteins. Cell 131, 887-900.

Mallette, F.A., Mattiroli, F., Cui, G., Young, L.C., Hendzel, M.J., Mer, G., Sixma, T.K., and Richard, S. (2012). RNF8- and RNF168-dependent degradation of KDM4A/JMJD2A triggers 53BP1 recruitment to DNA damage sites. EMBO J 31, 1865-1878. 
Margueron, R., and Reinberg, D. (2010). Chromatin structure and the inheritance of epigenetic information. Nat Rev Genet 11, 285-296.

Marteijn, J.A., Bekker-Jensen, S., Mailand, N., Lans, H., Schwertman, P., Gourdin, A.M., Dantuma, N.P., Lukas, J., and Vermeulen, W. (2009). Nucleotide excision repair-induced $\mathrm{H} 2 \mathrm{~A}$ ubiquitination is dependent on MDC1 and RNF8 and reveals a universal DNA damage response. J Cell Biol 186, 835-847.

Masumoto, H., Hawke, D., Kobayashi, R., and Verreault, A. (2005). A role for cell-cycle-regulated histone $\mathrm{H} 3$ lysine 56 acetylation in the DNA damage response. Nature 436, 294-298.

Mattiroli, F., Vissers, J.H., van Dijk, W.J., Ikpa, P., Citterio, E., Vermeulen, W., Marteijn, J.A., and Sixma, T.K. (2012). RNF168 ubiquitinates $\mathrm{K} 13-15$ on $\mathrm{H} 2 \mathrm{~A} / \mathrm{H} 2 \mathrm{AX}$ to drive DNA damage signaling. Cell 150, 1182-1195.

Messick, T.E., and Greenberg, R.A. (2009). The ubiquitin landscape at DNA double-strand breaks. J Cell Biol 187, 319-326.

Miller, K.M., and Jackson, S.P. (2012). Histone marks: repairing DNA breaks within the context of chromatin. Biochem Soc Trans 40, 370-376.

Miller, K.M., Tjeertes, J.V., Coates, J., Legube, G., Polo, S.E., Britton, S., and Jackson, S.P. (2010). Human HDAC1 and HDAC2 function in the DNA-damage response to promote DNA nonhomologous end-joining. Nat Struct Mol Biol 17, 1144-1151.

Miyamoto, N., Izumi, H., Noguchi, T., Nakajima, Y., Ohmiya, Y., Shiota, M., Kidani, A., Tawara, A., and Kohno, K. (2008). Tip60 is regulated by circadian transcription factor clock and is involved in cisplatin resistance. J Biol Chem 283, 18218-18226.

Morrison, A.J., Highland, J., Krogan, N.J., Arbel-Eden, A., Greenblatt, J.F., Haber, J.E., and Shen, X. (2004). INO80 and gamma-H2AX interaction links ATP-dependent chromatin remodeling to DNA damage repair. Cell 119, 767-775.

Mosammaparast, N., Kim, H., Laurent, B., Zhao, Y., Lim, H.J., Majid, M.C., Dango, S., Luo, Y., Hempel, K., Sowa, M.E., Gygi, S.P., Steen, H., Harper, J.W., Yankner, B., and Shi, Y. (2013). The histone demethylase LSD1/KDM1A promotes the DNA damage response. J Cell Biol 203, 457-470.

Mosbech, A., Lukas, C., Bekker-Jensen, S., and Mailand, N. (2013). The deubiquitylating enzyme USP44 counteracts the DNA double-strand break response mediated by the RNF8 and RNF168 ubiquitin ligases. J Biol Chem 288, 16579-16587.

Moyal, L., Lerenthal, Y., Gana-Weisz, M., Mass, G., So, S., Wang, S.Y., Eppink, B., Chung, Y.M., Shalev, G., Shema, E., Shkedy, D., Smorodinsky, N.I., van Vliet, N., Kuster, B., Mann, M., Ciechanover, A., Dahm-Daphi, J., Kanaar, R., Hu, M.C., Chen, D.J., Oren, M., and Shiloh, Y. (2011). Requirement of ATM-dependent monoubiquitylation of histone H2B for timely repair of DNA double-strand breaks. Mol Cell 41, 529-542.

Munoz-Galvan, S., Jimeno, S., Rothstein, R., and Aguilera, A. (2013). Histone H3K56 acetylation, Rad52, and non-DNA repair factors control double-strand break repair choice with the sister chromatid. PLoS Genet 9, e1003237.

Murr, R., Loizou, J.I., Yang, Y.G., Cuenin, C., Li, H., Wang, Z.Q., and Herceg, Z. (2006). Histone acetylation by Trap-Tip60 modulates loading of repair proteins and repair of DNA double-strand breaks. Nat Cell Biol 8, 91-99.

Nakada, S., Chen, G.I., Gingras, A.C., and Durocher, D. (2008). PP4 is a gamma $\mathrm{H} 2 \mathrm{AX}$ phosphatase required for recovery from the DNA damage checkpoint. EMBO Rep 9, 1019-1026.

Nakamura, K., Kato, A., Kobayashi, J., Yanagihara, H., Sakamoto, S., Oliveira, D.V., Shimada, M., Tauchi, H., Suzuki, H., Tashiro, S., Zou, L., and Komatsu, K. (2011). Regulation of homologous recombination by RNF20-dependent H2B ubiquitination. Mol Cell 41, 515-528.

Nakamura, T.M., Du, L.L., Redon, C., and Russell, P. (2004). Histone $\mathrm{H} 2 \mathrm{~A}$ phosphorylation controls $\mathrm{Crb} 2$ recruitment at DNA breaks, maintains checkpoint arrest, and influences DNA repair in fission yeast. Mol Cell Biol 24, 6215-6230.

Nottke, A.C., Beese-Sims, S.E., Pantalena, L.F., Reinke, V., Shi, Y., and Colaiacovo, M.P. (2011). SPR-5 is a histone H3K4 demethylase with a role in meiotic double-strand break repair. Proc Natl Acad Sci USA
108, 12805-12810.

O'Hagan, H.M., Mohammad, H.P., and Baylin, S.B. (2008). Double strand breaks can initiate gene silencing and SIRT1-dependent onset of DNA methylation in an exogenous promoter CpG island. PLoS Genet 4, e1000155.

Oda, H., Hubner, M.R., Beck, D.B., Vermeulen, M., Hurwitz, J., Spector, D.L., and Reinberg, D. (2010). Regulation of the histone H4 monomethylase PR-Set7 by CRL4(Cdt2)-mediated PCNA-dependent degradation during DNA damage. Mol Cell 40, 364-376.

Oda, H., Okamoto, I., Murphy, N., Chu, J., Price, S.M., Shen, M.M., Torres-Padilla, M.E., Heard, E., and Reinberg, D. (2009). Monomethylation of histone H4-lysine 20 is involved in chromosome structure and stability and is essential for mouse development. Mol Cell Biol 29, 2278-2295.

Ontoso, D., Acosta, I., van Leeuwen, F., Freire, R., and San-Segundo, P.A. (2013). Dot1-dependent histone H3K79 methylation promotes activation of the Mek1 meiotic checkpoint effector kinase by regulating the Hop1 adaptor. PLoS Genet 9, e1003262.

Osley, M.A., Tsukuda, T., and Nickoloff, J.A. (2007). ATP-dependent chromatin remodeling factors and DNA damage repair. Mutat Res 618, 65-80.

Pai, C.C., Deegan, R.S., Subramanian, L., Gal, C., Sarkar, S., Blaikley, E.J., Walker, C., Hulme, L., Bernhard, E., Codlin, S., Bahler, J., Allshire, R., Whitehall, S., and Humphrey, T.C. (2014). A histone H3K36 chromatin switch coordinates DNA double-strand break repair pathway choice. Nat Commun 5, 4091.

Pan, M.R., Peng, G., Hung, W.C., and Lin, S.Y. (2011). Monoubiquitination of $\mathrm{H} 2 \mathrm{AX}$ protein regulates DNA damage response signaling. J Biol Chem 286, 28599-28607.

Papamichos-Chronakis, M., Krebs, J.E., and Peterson, C.L. (2006). Interplay between Ino80 and Swr1 chromatin remodeling enzymes regulates cell cycle checkpoint adaptation in response to DNA damage. Genes Dev 20, 2437-2449.

Papazyan, R., Voronina, E., Chapman, J.R., Luperchio, T.R., Gilbert, T.M., Meier, E., Mackintosh, S.G., Shabanowitz, J., Tackett, A.J., Reddy, K.L., Coyne, R.S., Hunt, D.F., Liu, Y., and Taverna, S.D. (2014). Methylation of histone H3K23 blocks DNA damage in pericentric heterochromatin during meiosis. Elife 3, e02996.

Park, J.H., Park, E.J., Lee, H.S., Kim, S.J., Hur, S.K., Imbalzano, A.N., and Kwon, J. (2006). Mammalian SWI/SNF complexes facilitate DNA double-strand break repair by promoting gamma-H2AX induction. EMBO J 25, 3986-3997.

Paull, T.T., Rogakou, E.P., Yamazaki, V., Kirchgessner, C.U., Gellert, M., and Bonner, W.M. (2000). A critical role for histone H2AX in recruitment of repair factors to nuclear foci after DNA damage. Curr Biol 10, 886-895.

Pei, H., Zhang, L., Luo, K., Qin, Y., Chesi, M., Fei, F., Bergsagel, P.L., Wang, L., You, Z., and Lou, Z. (2011). MMSET regulates histone H4K20 methylation and 53BP1 accumulation at DNA damage sites. Nature 470, 124-128.

Peng, J.C., and Karpen, G.H. (2009). Heterochromatic genome stability requires regulators of histone $\mathrm{H} 3 \mathrm{~K} 9$ methylation. PLoS Genet 5, e1000435.

Pfister, S.X., Ahrabi, S., Zalmas, L.P., Sarkar, S., Aymard, F., Bachrati, C.Z., Helleday, T., Legube, G., La Thangue, N.B., Porter, A.C., and Humphrey, T.C. (2014). SETD2-dependent histone H3K36 trimethylation is required for homologous recombination repair and genome stability. Cell Rep 7, 2006-2018.

Pickart, C.M. (2001). Mechanisms underlying ubiquitination. Annu Rev Biochem 70, 503-533.

Polo, S.E., and Jackson, S.P. (2011). Dynamics of DNA damage response proteins at DNA breaks: a focus on protein modifications. Genes Dev $25,409-433$.

Poulsen, M., Lukas, C., Lukas, J., Bekker-Jensen, S., and Mailand, N. (2012). Human RNF169 is a negative regulator of the ubiquitin-dependent response to DNA double-strand breaks. J Cell Biol 197, 189-199.

Qian, M.X., Pang, Y., Liu, C.H., Haratake, K., Du, B.Y., Ji, D.Y., Wang, G.F., Zhu, Q.Q., Song, W., Yu, Y., Zhang, X.X., Huang, H.T., Miao, 
S., Chen, L.B., Zhang, Z.H., Liang, Y.N., Liu, S., Cha, H., Yang, D., Zhai, Y., Komatsu, T., Tsuruta, F., Li, H., Cao, C., Li, W., Li, G.H., Cheng, Y., Chiba, T., Wang, L., Goldberg, A.L., Shen, Y., and Qiu, X.B. (2013). Acetylation-mediated proteasomal degradation of core histones during DNA repair and spermatogenesis. Cell 153, 1012-1024.

Qin, S., and Parthun, M.R. (2002). Histone H3 and the histone acetyltransferase Hat1p contribute to DNA double-strand break repair. Mol Cell Biol 22, 8353-8365.

Rogakou, E.P., Boon, C., Redon, C., and Bonner, W.M. (1999). Megabase chromatin domains involved in DNA double-strand breaks in vivo. J Cell Biol 146, 905-916.

Rogakou, E.P., Pilch, D.R., Orr, A.H., Ivanova, V.S., and Bonner, W.M. (1998). DNA double-stranded breaks induce histone H2AX phosphorylation on serine 139. J Biol Chem 273, 5858-5868.

Rossetto, D., Truman, A.W., Kron, S.J., and Cote, J. (2010). Epigenetic modifications in double-strand break DNA damage signaling and repair. Clin Cancer Res 16, 4543-4552.

Rossodivita, A.A., Boudoures, A.L., Mecoli, J.P., Steenkiste, E.M., Karl, A.L., Vines, E.M., Cole, A.M., Ansbro, M.R., and Thompson, J.S. (2014). Histone H3 K79 methylation states play distinct roles in UV-induced sister chromatid exchange and cell cycle checkpoint arrest in Saccharomyces cerevisiae. Nucleic Acids Res 42, 6286-6299.

Roth, S.Y., Denu, J.M., and Allis, C.D. (2001). Histone acetyltransferases. Annu Rev Biochem 70, 81-120.

Sakaguchi, A., and Steward, R. (2007). Aberrant monomethylation of histone H4 lysine 20 activates the DNA damage checkpoint in Drosophila melanogaster. J Cell Biol 176, 155-162.

Sancar, A., Lindsey-Boltz, L.A., Unsal-Kacmaz, K., and Linn, S. (2004). Molecular mechanisms of mammalian DNA repair and the DNA damage checkpoints. Annu Rev Biochem 73, 39-85.

Sanders, S.L., Portoso, M., Mata, J., Bahler, J., Allshire, R.C., and Kouzarides, T. (2004). Methylation of histone H4 lysine 20 controls recruitment of Crb2 to sites of DNA damage. Cell 119, 603-614.

Sasaki, T., Lynch, K.L., Mueller, C.V., Friedman, S., Freitag, M., and Lewis, Z.A. (2014). Heterochromatin controls gammaH2A localization in Neurospora crassa. Eukaryot Cell 13, 990-1000.

Savic, V., Yin, B., Maas, N.L., Bredemeyer, A.L., Carpenter, A.C., Helmink, B.A., Yang-Iott, K.S., Sleckman, B.P., and Bassing, C.H. (2009). Formation of dynamic gamma-H2AX domains along broken DNA strands is distinctly regulated by ATM and MDC1 and dependent upon H2AX densities in chromatin. Mol Cell 34, 298-310.

Schneider, A.C., Heukamp, L.C., Rogenhofer, S., Fechner, G., Bastian, P.J., von Ruecker, A., Muller, S.C., and Ellinger, J. (2011). Global histone H4K20 trimethylation predicts cancer-specific survival in patients with muscle-invasive bladder cancer. BJU Int 108, E290-E296.

Schotta, G., Sengupta, R., Kubicek, S., Malin, S., Kauer, M., Callen, E., Celeste, A., Pagani, M., Opravil, S., De La Rosa-Velazquez, I.A., Espejo, A., Bedford, M.T., Nussenzweig, A., Busslinger, M., and Jenuwein, T. (2008). A chromatin-wide transition to H4K20 monomethylation impairs genome integrity and programmed DNA rearrangements in the mouse. Genes Dev 22, 2048-2061.

Seiler, D.M., Rouquette, J., Schmid, V.J., Strickfaden, H., Ottmann, C., Drexler, G.A., Mazurek, B., Greubel, C., Hable, V., Dollinger, G., Cremer, T., and Friedl, A.A. (2011). Double-strand break-induced transcriptional silencing is associated with loss of tri-methylation at H3K4. Chromosome Res 19, 883-899.

Shahbazian, M.D., and Grunstein, M. (2007). Functions of site-specific histone acetylation and deacetylation. Annu Rev Biochem 76, 75-100.

Shanbhag, N.M., Rafalska-Metcalf, I.U., Balane-Bolivar, C., Janicki, S.M., and Greenberg, R.A. (2010). ATM-dependent chromatin changes silence transcription in cis to DNA double-strand breaks. Cell 141, 970-981.

Sharma, G.G., So, S., Gupta, A., Kumar, R., Cayrou, C., Avvakumov, N., Bhadra, U., Pandita, R.K., Porteus, M.H., Chen, D.J., Cote, J., and Pandita, T.K. (2010). MOF and histone H4 acetylation at lysine 16 are critical for DNA damage response and double-strand break repair. Mol Cell Biol 30, 3582-3595.

Shen, C., Wang, D., Liu, X., Gu, B., Du, Y., Wei, F.Z., Cao, L.L., Song, B., Lu, X., Yang, Q., Zhu, Q., Hou, T., Li, M., Wang, L., Wang, H.,
Zhao, Y., Yang, Y., and Zhu, W.G. (2015). SET7/9 regulates cancer cell proliferation by influencing beta-catenin stability. FASEB J 29, 4313-1323

Shogren-Knaak, M., Ishii, H., Sun, J.M., Pazin, M.J., Davie, J.R., and Peterson, C.L. (2006). Histone H4-K16 acetylation controls chromatin structure and protein interactions. Science 311, 844-847.

Shroff, R., Arbel-Eden, A., Pilch, D., Ira, G., Bonner, W.M., Petrini, J.H., Haber, J.E., and Lichten, M. (2004). Distribution and dynamics of chromatin modification induced by a defined DNA double-strand break. Curr Biol 14, 1703-1711.

Smith, E.R., Cayrou, C., Huang, R., Lane, W.S., Cote, J., and Lucchesi, J.C. (2005). A human protein complex homologous to the Drosophila MSL complex is responsible for the majority of histone $\mathrm{H} 4$ acetylation at lysine 16. Mol Cell Biol 25, 9175-9188.

Stewart, G.S., Panier, S., Townsend, K., Al-Hakim, A.K., Kolas, N.K., Miller, E.S., Nakada, S., Ylanko, J., Olivarius, S., Mendez, M., Oldreive, C., Wildenhain, J., Tagliaferro, A., Pelletier, L., Taubenheim, N., Durandy, A., Byrd, P.J., Stankovic, T., Taylor, A.M., and Durocher, D. (2009). The RIDDLE syndrome protein mediates a ubiquitin-dependent signaling cascade at sites of DNA damage. Cell 136, 420-434.

Stiff, T., O'Driscoll, M., Rief, N., Iwabuchi, K., Lobrich, M., and Jeggo, P.A. (2004). ATM and DNA-PK function redundantly to phosphorylate H2AX after exposure to ionizing radiation. Cancer Res 64, 2390-2396.

Strahl, B.D., and Allis, C.D. (2000). The language of covalent histone modifications. Nature 403, 41-45.

Stucki, M., Clapperton, J.A., Mohammad, D., Yaffe, M.B., Smerdon, S.J., and Jackson, S.P. (2005). MDC1 directly binds phosphorylated histone $\mathrm{H} 2 \mathrm{AX}$ to regulate cellular responses to DNA double-strand breaks. Cell $123,1213-1226$.

Suganuma, T., and Workman, J.L. (2008). Crosstalk among histone modifications. Cell 135, 604-607.

Sulli, G., Di Micco, R., and d'Adda di Fagagna, F. (2012). Crosstalk between chromatin state and DNA damage response in cellular senescence and cancer. Nat Rev Cancer 12, 709-720.

Sun, Y., Jiang, X., and Price, B.D. (2010). Tip60: connecting chromatin to DNA damage signaling. Cell Cycle 9, 930-936.

Sun, Y., Jiang, X., Xu, Y., Ayrapetov, M.K., Moreau, L.A., Whetstine, J.R., and Price, B.D. (2009). Histone H3 methylation links DNA damage detection to activation of the tumour suppressor Tip60. Nat Cell Biol 11, 1376-1382.

Takahashi, A., Imai, Y., Yamakoshi, K., Kuninaka, S., Ohtani, N., Yoshimoto, S., Hori, S., Tachibana, M., Anderton, E., Takeuchi, T., Shinkai, Y., Peters, G., Saya, H., and Hara, E. (2012). DNA damage signaling triggers degradation of histone methyltransferases through APC/C(Cdh1) in senescent cells. Mol Cell 45, 123-131.

Talbert, P.B., and Henikoff, S. (2010). Histone variants-ancient wrap artists of the epigenome. Nat Rev Mol Cell Biol 11, 264-275.

Tamburini, B.A., and Tyler, J.K. (2005). Localized histone acetylation and deacetylation triggered by the homologous recombination pathway of double-strand DNA repair. Mol Cell Biol 25, 4903-4913.

Tan, M., Luo, H., Lee, S., Jin, F., Yang, J.S., Montellier, E., Buchou, T., Cheng, Z., Rousseaux, S., Rajagopal, N., Lu, Z., Ye, Z., Zhu, Q., Wysocka, J., Ye, Y., Khochbin, S., Ren, B., and Zhao, Y. (2011). Identification of 67 histone marks and histone lysine crotonylation as a new type of histone modification. Cell 146, 1016-1028.

Tang, J., Cho, N.W., Cui, G., Manion, E.M., Shanbhag, N.M., Botuyan, M.V., Mer, G., and Greenberg, R.A. (2013). Acetylation limits 53BP1 association with damaged chromatin to promote homologous recombination. Nat Struct Mol Biol 20, 317-325.

Tateishi, K., Okada, Y., Kallin, E.M., and Zhang, Y. (2009). Role of $\mathrm{Jhdm} 2 \mathrm{a}$ in regulating metabolic gene expression and obesity resistance. Nature 458, 757-761.

Tatum, D., and Li, S. (2011). Evidence that the histone methyltransferase Dot1 mediates global genomic repair by methylating histone $\mathrm{H} 3$ on lysine 79. J Biol Chem 286, 17530-17535.

Tjeertes, J.V., Miller, K.M., and Jackson, S.P. (2009). Screen for DNA-damage-responsive histone modifications identifies H3K9Ac and H3K56Ac in human cells. EMBO J 28, 1878-1889. 
Turner, B.M., Birley, A.J., and Lavender, J. (1992). Histone H4 isoforms acetylated at specific lysine residues define individual chromosomes and chromatin domains in Drosophila polytene nuclei. Cell 69, 375-384.

Unal, E., Arbel-Eden, A., Sattler, U., Shroff, R., Lichten, M., Haber, J.E., and Koshland, D. (2004). DNA damage response pathway uses histone modification to assemble a double-strand break-specific cohesin domain. Mol Cell 16, 991-1002.

Utley, R.T., Lacoste, N., Jobin-Robitaille, O., Allard, S., and Cote, J. (2005). Regulation of NuA4 histone acetyltransferase activity in transcription and DNA repair by phosphorylation of histone H4. Mol Cell Biol 25, 8179-8190.

van Attikum, H., Fritsch, O., Hohn, B., and Gasser, S.M. (2004). Recruitment of the INO80 complex by H2A phosphorylation links ATP-dependent chromatin remodeling with DNA double-strand break repair. Cell 119, 777-788.

Vempati, R.K., Jayani, R.S., Notani, D., Sengupta, A., Galande, S., and Haldar, D. (2010). p300-mediated acetylation of histone H3 lysine 56 functions in DNA damage response in mammals. J Biol Chem 285, 28553-28564.

Voigt, P., Tee, W.W., and Reinberg, D. (2013). A double take on bivalent promoters. Genes Dev 27, 1318-1338.

Wagner, K.W., Alam, H., Dhar, S.S., Giri, U., Li, N., Wei, Y., Giri, D., Cascone, T., Kim, J.H., Ye, Y., Multani, A.S., Chan, C.H., Erez, B., Saigal, B., Chung, J., Lin, H.K., Wu, X., Hung, M.C., Heymach, J.V., and Lee, M.G. (2013). KDM2A promotes lung tumorigenesis by epigenetically enhancing ERK1/2 signaling. J Clin Invest 123, 5231-5246.

Wakeman, T.P., Wang, Q., Feng, J., and Wang, X.-F. (2012). Bat3 facilitates $\mathrm{H} 3 \mathrm{~K} 79$ dimethylation by DOT1L and promotes DNA damage-induced 53BP1 foci at G1/G2 cell-cycle phases. EMBO J 31, 2169-2181.

Wang, B., and Elledge, S.J. (2007). Ubc13/Rnf8 ubiquitin ligases control foci formation of the Rap80/Abraxas/Brca1/Brcc36 complex in response to DNA damage. Proc Natl Acad Sci USA 104, 20759-20763.

Wang, D., Zhou, J., Liu, X., Lu, D., Shen, C., Du, Y., Wei, F.Z., Song, B., Lu, X., Yu, Y., Wang, L., Zhao, Y., Wang, H., Yang, Y., Akiyama, Y., Zhang, H., and Zhu, W.G. (2013). Methylation of SUV39H1 by SET7/9 results in heterochromatin relaxation and genome instability. Proc Natl Acad Sci USA 110, 5516-5521.

Wang, H., Zhai, L., Xu, J., Joo, H.-Y., Jackson, S., Erdjument-Bromage, H., Tempst, P., Xiong, Y., and Zhang, Y. (2006). Histone H3 and H4 ubiquitylation by the CUL4-DDB-ROC1 ubiquitin ligase facilitates cellular response to DNA damage. Mol Cell 22, 383-394.

Ward, I.M., and Chen, J. (2001). Histone H2AX is phosphorylated in an ATR-dependent manner in response to replicational stress. J Biol Chem 276, 47759-47762.

Williamson, E.A., Wray, J.W., Bansal, P., and Hromas, R. (2012). Overview for the histone codes for DNA repair. Prog Mol Biol Transl Sci 110, 207-227.
Wu, J., Huen, M.S., Lu, L.Y., Ye, L., Dou, Y., Ljungman, M., Chen, J., and $\mathrm{Yu}, \mathrm{X}$. (2009). Histone ubiquitination associates with BRCA1-dependent DNA damage response. Mol Cell Biol 29, 849-860.

Wu, W., Nishikawa, H., Fukuda, T., Vittal, V., Asano, M., Miyoshi, Y., Klevit, R.E., and Ohta, T. (2015). Interaction of BARD1 and HP1 is required for BRCA1 retention at sites of DNA damage. Cancer Res 75, 1311-1321.

Wurtele, H., Kaiser, G.S., Bacal, J., St-Hilaire, E., Lee, E.H., Tsao, S., Dorn, J., Maddox, P., Lisby, M., Pasero, P., and Verreault, A. (2012). Histone $\mathrm{H} 3$ lysine 56 acetylation and the response to DNA replication fork damage. Mol Cell Biol 32, 154-172.

Wysocki, R., Javaheri, A., Allard, S., Sha, F., Cote, J., and Kron, S.J. (2005). Role of Dot1-dependent histone H3 methylation in G1 and S phase DNA damage checkpoint functions of Rad9. Mol Cell Biol 25, 8430-8443.

Xiao, A., Li, H., Shechter, D., Ahn, S.H., Fabrizio, L.A., Erdjument-Bromage, H., Ishibe-Murakami, S., Wang, B., Tempst, P., Hofmann, K., Patel, D.J., Elledge, S.J., and Allis, C.D. (2009). WSTF regulates the H2A.X DNA damage response via a novel tyrosine kinase activity. Nature 457, 57-62.

Xie, A., Odate, S., Chandramouly, G., and Scully, R. (2010). H2AX post-translational modifications in the ionizing radiation response and homologous recombination. Cell Cycle 9, 3602-3610.

Xie, A., Puget, N., Shim, I., Odate, S., Jarzyna, I., Bassing, C.H., Alt, F.W., and Scully, R. (2004). Control of sister chromatid recombination by histone H2AX. Mol Cell 16, 1017-1025.

Xu, Y., Sun, Y., Jiang, X., Ayrapetov, M.K., Moskwa, P., Yang, S., Weinstock, D.M., and Price, B.D. (2010). The p400 ATPase regulates nucleosome stability and chromatin ubiquitination during DNA repair. $\mathrm{J}$ Cell Biol 191, 31-43.

Yan, Q., Dutt, S., Xu, R., Graves, K., Juszczynski, P., Manis, J.P., and Shipp, M.A. (2009). BBAP monoubiquitylates histone $\mathrm{H} 4$ at lysine 91 and selectively modulates the DNA damage response. Mol Cell 36, 110-120.

Yang, X., Li, L., Liang, J., Shi, L., Yang, J., Yi, X., Zhang, D., Han, X., Yu, N., and Shang, Y. (2013). Histone acetyltransferase 1 promotes homologous recombination in DNA repair by facilitating histone turnover. J Biol Chem 288, 18271-18282.

Young, L.C., McDonald, D.W., and Hendzel, M.J. (2013). Kdm4b histone demethylase is a DNA damage response protein and confers a survival advantage following gamma-irradiation. J Biol Chem 288, 21376-21388.

Yu, H., Pak, H., Hammond-Martel, I., Ghram, M., Rodrigue, A., Daou, S., Barbour, H., Corbeil, L., Hebert, J., Drobetsky, E., Masson, J.Y., Di Noia, J.M., and Affar el, B. (2014). Tumor suppressor and deubiquitinase BAP1 promotes DNA double-strand break repair. Proc Natl Acad Sci USA 111, 285-290.

Yun, M., Wu, J., Workman, J.L., and Li, B. (2011). Readers of histone modifications. Cell Res 21, 564-578.

Open Access This article is distributed under the terms of the Creative Commons Attribution License which permits any use, distribution, and reproduction in any medium, provided the original author(s) and source are credited. 